\title{
Connecting chert sources of Sicily with Neolithic chert artefacts of Malta.
}

Chatzimpaloglou P. ${ }^{1}$, French, C. ${ }^{1}$, Pedley, M. ${ }^{2}$ and Stoddart, S. ${ }^{1}$

${ }^{1}$ Department of Archaeology, University of Cambridge, United Kingdom pc529@cam.ac.uk, caif2@cam.ac.uk, ss16@cam.ac.uk

${ }^{2}$ Department of Geography and Geology, University of Hull, United Kingdom H.M.Pedley@ hull.ac.uk

\begin{abstract}
This article presents the results of a provenance study between late-Neolithic chert artefacts from Malta and chert sources of Sicily. It is part of a larger geoarchaeological research dedicated to investigate whether the cherts used for stone artefacts represent indigenous exploitation or results from longer-distance networks. Chert is a raw material commonly used in prehistory for tool crafting and with abundant geological sources in the broader Mediterranean region. However, the features of most of these sources are unknown and no detailed data regarding their geochemical characteristics and composition are available. The lithic assemblages of late Neolithic Malta are abundant with nonlocal chert finds and their origin will contribute to inferences about the role of Malta within the broader Mediterranean social landscape and raw-material network of this period.

The paper uses macroscopic examination to distinguish the different chert varieties in the assemblages and the non-destructive LA-ICP-MS technique to identify groups with specific geochemical characteristics/signature. The field and lab-based work suggest multiple sources for the chert artefacts and most significantly, presents strong evidence of artefacts having almost identical geochemical signature with specific chert sources from southeast Sicily. These are the first highly reliable results confirming a connection between these two locations and strongly suggests the existence of seafaring in this area during the late Neolithic.
\end{abstract}

Keywords: Provenance, chert artefacts, raw-material networks, Neolithic Malta 


\section{Introduction}

Archaeological research has found evidence of a highly advanced pre-urban community in the Maltese archipelago (Malone et al., 2009; Vella, 2009), a group of isolated islands (Malta, Gozo and Comino) which lie at the centre of the Mediterranean Sea (Figs. 1 and 2). This society constructed the well-known Stone Temples from approximately 3800 to 2300 BC. Although this prehistoric society has been investigated for many decades, there are many aspects of it that remain poorly understood. For example, we are unsure how this community arrived on these islands, how they managed to survive and thrive in an environment with limited access to resources, and what opportunities did they have for forming relationships with neighbouring areas. The apparent absence of writing and evidence of seafaring make these questions difficult to answer with conventional archaeological methodologies. An alternative strategy is necessary to address these questions.

During prehistoric times, stone resources played a significant role for Mediterranean communities, primarily for making chipped stone tools (Skarpelis et al., 2017). The origin of the raw materials (Brandl, M., 2010; Bressy et al, 2008; Williams-Thorpe, 1995) and the technologies employed on the tools (Odell, G., H. 2000; Larson, 1994; Pelegrin, J. 1990) have been investigated in order to understand the identities of prehistoric people and their social organization . Furthermore, they have contributed to identification of trade/exchange networks and possible interactions between these societies (Moutsiou and Kassianidou, 2019; Skarpelis et al., 2017; Tykot, 1996 and 1997). Therefore, addressing the provenance of the lithic assemblages from late Neolithic sites on Malta is a new potential avenue of research that may be able to address the remaining uncertainties of this community.

Although sourcing studies on obsidian are well-established in the Mediterranean region (Cann and Renfrew, 1964; Tykot, 1996; Williams-Thorpe, 1995; Robb and Farr, 2005), little is known about the chert sources and their characteristics. The main reason is that chert rocks are considered significantly more difficult to characterize than obsidian (Skarpelis et al., 2017). Moreover, their greater geochemical and petrographic heterogeneity makes more difficult to clearly discriminate between products of different sources (Luedtke, 1992). Hence a geoarchaeological approach is necessary to distinguish between the different geological sources, before attempting to connect them with the chert components of lithic assemblages at archaeological sites.

This paper presents a geoarchaeological investigation of two chert assemblages from later Neolithic Malta. It uses a non-destructive and geologically grounded methodology and pin-points Sicilian sources from which Maltese chert artefacts probably originated. The outcome of this research 
is not restricted to sourcing lithics but also to other, still unknown, aspects of the broader Neolithic Mediterranean region. Although there is no evidence of sailing activity, the connection of two insular locations is at least an indirect proof of seafaring and raw-material networks. In addition, the scientific verification of the exploitation of chert sources is a reliable method for accurately reconstructing these networks. This can further contribute to ideas about the level of access to resources and possible interactions with other communities.

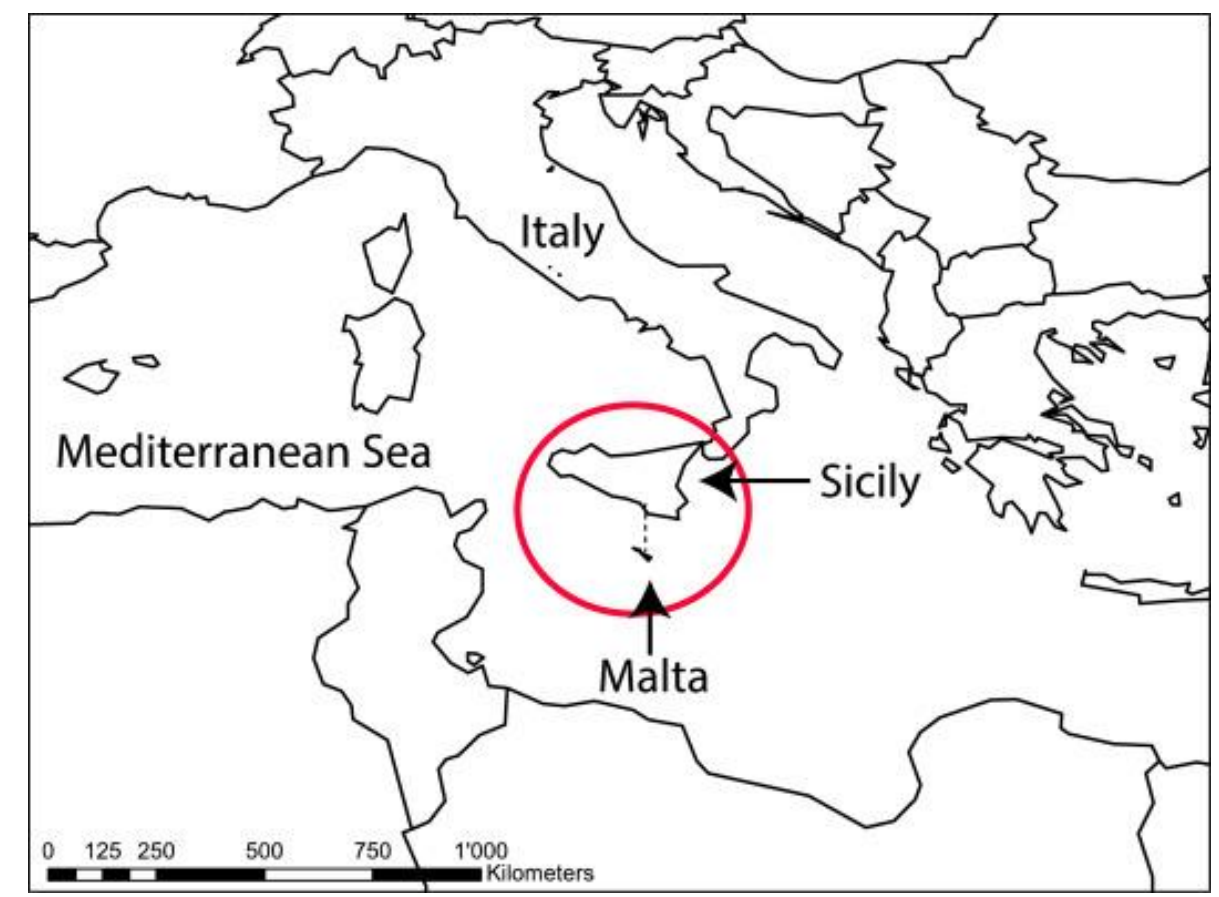

Figure 1. Map of the central Mediterranean Sea. The red circle points the position of Sicily and Malta. 


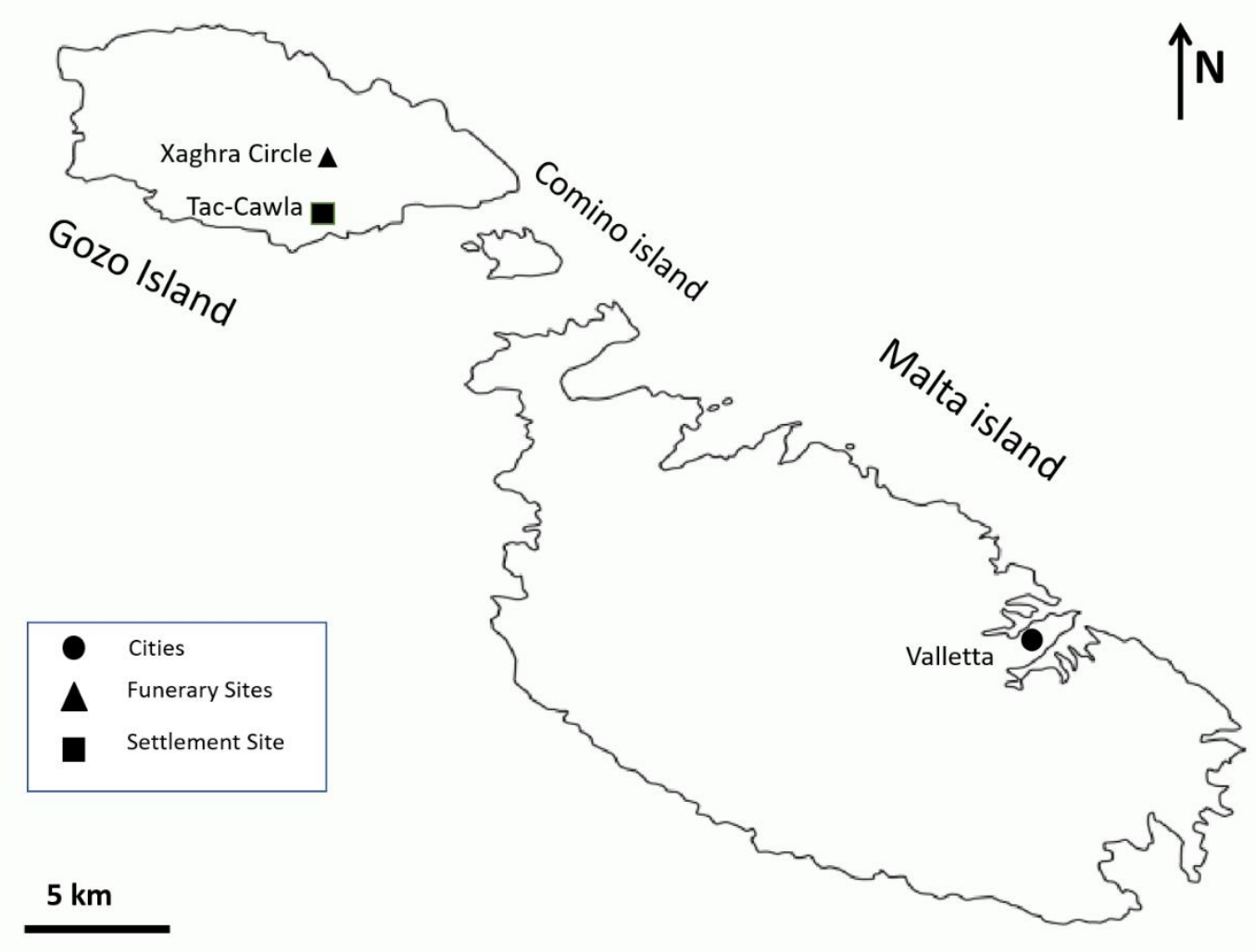

Figure 2. Map of the Maltese Islands. It shows the main islands and points the location of the archaelogical sities and the capital (Valletta).

\section{Archaeological Background}

\subsection{The Prehistory of Malta}

The prehistoric society that built these monuments of the Maltese Islands has been established as one of the most precocious pre-urban communities of the world (Malone et al., 2009). The earliest evidence for human occupation of the Maltese Islands goes back to the early Neolithic period, which would now be placed at c. 5800 to $5500 \mathrm{BC}$ thanks to the dating program of the FRAGSUS project. This date is also considered the onset of the Pre-Temple period of the Maltese Islands, which lasted until c. 4100 B.C. The Pre-Temple period encapsulated sites of human occupation in open areas and caves.

The Stone Temples were constructed and modified from approximately 3800 to 2300 B.C. (Malone et al., 2009). In association with these late Neolithic sites, important chert assemblages have been discovered. Most of these finds are derived from local chert material, but many artefacts are related with non-local chert rocks. There is an existing theory suggesting a Sicilian origin, based on the proximity of Sicily with Malta and the known chert outcrops of this island (Vella, 2008). This paper reports on the geoarchaeological project that was developed to test this theory and provides evidence of connections between these two insular locations of the central Mediterranean region, concentrating on the chert artefacts recovered from the funerary site of Brochtorff-Xaghra Circle and the settlement site of Tać-Ċawla, both on Gozo. 


\subsection{Brochtorff-Xaghra Circle (Burial Site)}

The Brochtorff-Xaghra Circle, also known as the Xaghra Stone Circle and the Gozo Stone Circle, is located on the southern crest of the Xaghra plateau (Malone et al., 2009) (Fig. 2). The Circle was recognized by 18th century antiquarian travelers, with Otto Bayer being the first to excavate the site. However, it was not until 1987 that the site was fully investigated and its importance recognized. The excavation project between 1987 and 1994, led to the discovery of an underground (cave) funerary complex containing more than 250,000 human bones and a rich collection of prehistoric artefacts (ibid.). The evidence collected from the excavation showed that the Circle was in use from approximately $3400 \mathrm{BC}$ to $2300 \mathrm{BC}$. The evidence suggests that during this period it had a cultural use (burial site), while later it changed use to a domestic occupation.

\subsection{Tać-Cawla (Settlement Site)}

The Tać-Ċawla site is a prehistoric settlement located in the southern suburbs of Victoria City on Gozo (the capital) (Fig. 2). The site was discovered in the late 1980s, but only limited information was known as it was never properly excavated. The first comprehensive investigation of the site was conducted in 2014 under the FRAGSUS project and is now in course of publication (Malone et al., forthcoming). The first results suggest that Tać-Ċawla was a settlement dating from c. 3800 to 1800 B.C.

\section{Chert rocks and the geological background of the Sicily Island}

\subsection{Chert as raw material}

Cherts are fine-grained, dense and very hard sedimentary rocks, which are composed predominantly of silicon dioxide $\left(\mathrm{SiO}_{2}\right)$ minerals (>90\%). They break with a conchoidal fracture, often producing very sharp edges and variations in colour. Cherts are common but not abundant rocks in the geologic record, which range in age from the Precambrian to the Quaternary (Boggs, 2009; Tucker, 2001). The origin of silicon dioxide $\left(\mathrm{SiO}_{2}\right)$ is considered to be either entirely biogenic or a product of hydrothermal activity (Tucker, 2001; Maliva et al. 2005; Shen, et al. 2018).

They might be composed dominantly of $\mathrm{Si}$, but can include other major elements such as $\mathrm{Al}, \mathrm{Fe}$, $\mathrm{Mn}, \mathrm{Ca}$, and Ti (Luedtke, 1992). In addition, cherts also contain minor amount of trace (e.g. Sr, Th) and rare-earth elements (REE). Mineralogically they mainly consist of quartz, but other polymorphs of silica have been reported (e.g. Opal-A). Lastly, the chert outcrops are commonly found intercalating host formations such as limestone, and they appear in bedded or nodular form. 


\subsubsection{Chert vs Flint Debate}

The literature on Maltese prehistory (Malone et al. 2009; Vella, 2008) has used a variety of terms (e.g. chert and flint) to describe relevant lithics recovered from the sites. The geological research, however, has allocated specific petrological characteristics to each of these terms (Boggs, 2009; Tucker, 2001) and a proper geological investigation is necessary before choosing the appropriate one.

Chert is a general geological term used to define all concretions, nodules and tabular layers of amorphous siliceous precipitate dominantly composed of silicon dioxide $\left(\mathrm{SiO}_{2}\right)$. Additionally, it is not age specific and can occur throughout the stratigraphic column. In contrast, flint is an informal geological term and its use must be restricted to a specific variety of amorphous $\mathrm{SiO}_{2}$ originating within the Northwest European, Cretaceous Chalk Formation.

Unfortunately, the archaeological research mainly used these terms outside of their original context creating confusion between the disciplines. A petrologically focused paper is more appropriate to resolve the exact type of material found in Malta and Sicily. Until then, 'Flint' (frequently misused in an archaeological context) is not an appropriate term for use in this study. This paper will use the term "chert", which in respect of geology enclosed all the similar types of this rock formation.

\subsection{Geology of Sicily}

Sicily is the largest island in the centre of the Mediterranean (Fig. 1) and presents three main groups of geological formation, which are: a) the formations of the African continental margin (Hyblean Plateau), b) the formations of the "European group," and c) the formations related with volcanic activity (Catalano, 2004) (Fig. 3).

The African rock units are the sedimentary successions that consist of Mesozoic - Lower Miocene deep-water carbonates and cherts (locally named Sicilide, Imerese, Sicanian), and the Meso-Cenozoic shelf carbonates (Pedley, 1981). The "European group" consist of a Paleozoic - Mesozoic sedimentary succession and the 'Tethyan' rock units (from the former Tethys ocean). The volcanic formations are divided into two groups, which are related with the two cycles of volcanic activity on the Island (Cretaceous-Jurassic and Neocene-Quaternary respectively). 


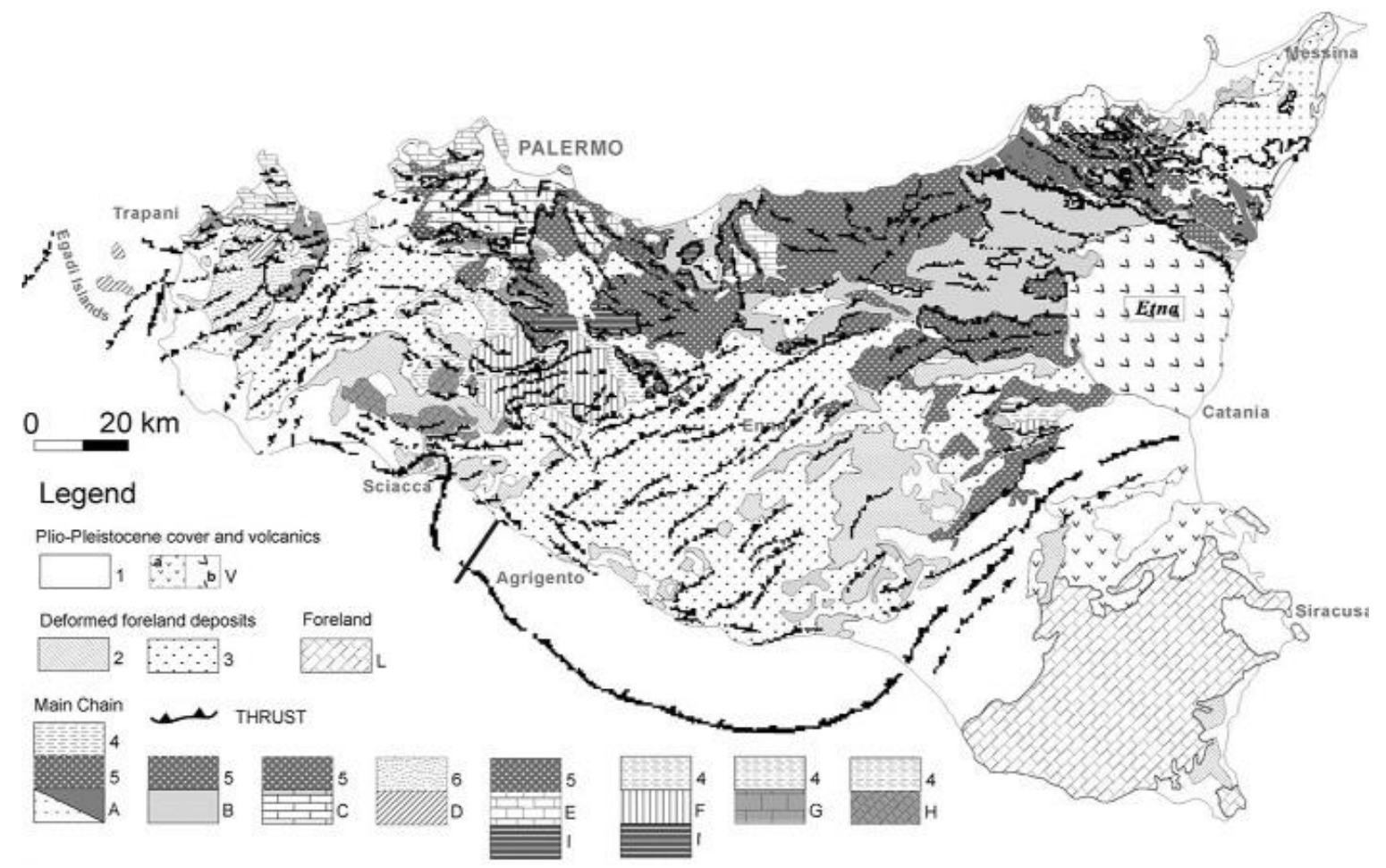

Figure 3. A modified geological map of Sicily (Catalano, 2004). 1.Pleistocene; 2-4. Deformed foreland basins (L. Pleistocene to L. Miocene); 5. Flysch units (L. Miocene-U. Oligocene); 6. Shelf margin (L. Miocene-U. Oligocene); A. Calabrian tectonic units (Oligocene-Paleozoic); B. Sicilide units (Oligocene-U. Mesozoic); C. Panormide units (Oligocene-Trias); D. Pre-Panormide units (Oligocene-Trias); E. Imerese units (Oligocene-U. Mesozoic); F. Sicanian units (Oligocene-U. Mesozoic); G.. Trapanese units (Oligocene-Trias); H. Saccense units (Oligocene-Trias); I. L. Permian-Middle Triassic allochthons; L. Hyblean units (L. Pleistocene-Trias); V. Volcanics: (a) Pliocene, (b) Pleistocene. 


\section{Materials and Methods}

\subsection{Field Research}

The fieldwork on Sicily was conducted in September 2016, with the collaboration of Cambridge University, and the Universities of Catania and Palermo. The investigation focused on the different types of chert formations located on the island, with the most important chert formations examined. During this fieldwork, the macroscopic characteristics of the chert outcrops were recorded, and 29 representative samples were collected. This was followed by work on Malta that included the indoor examination of the lithic assemblages of Brochtorff-Xaghra Circle and Tać-Ċawla. These assemblages are stored in the National Museum of Archaeology in Valletta. This research recorded the macroscopic features of the finds and selected 32 representative samples for further laboratory investigations.

The macroscopic examination in the field followed the baseline of the work provided by Crandell (2006) and Luedtke (1992). They suggested the examination of nine essential macroscopic characteristics: the type of material, colour, fabric, translucency, texture, lustre, grain, pattern and cortex. Although the investigated assemblages included artefacts of different rock materials and were not restricted to the chert type, the scope of this research focused only on the chert stone artefacts. The colour of the artefacts was described with the help of the Munsell rock colour book (2014). This increased the accuracy of the colour description and minimized the subjectivity of the researcher. The other seven features followed the terms and explanations provided in the work of Crandell (2006).

This stage was followed by employing a suite of laboratory methods (presented below) on the collected samples (geological and archaeological) in order to draw conclusions about the chert formations of Sicily and the chert artefact.

\subsection{Laboratory research}

The elementary analyses were performed using Laser Ablation- Inductively Coupled Plasma Mass Spectrometry (LA-ICP-MS), a technique used to determine the composition of the major, trace and rare earth elements (Speer, 2014; Neff, 2012). Through this method, 20 rock samples from Sicily and 27 archaeological samples from the two Neolithic assemblages were examined (tab. 1 and 2). The LAICP-MS equipment is located in the Department of Earth Sciences at the University of Cambridge. This high-resolution depth profiling technique employed a ESI NWR193 excimer Laser Ablation system interfaced to the Nexion 350D ICP-MS. A $100 \mu \mathrm{m}$ diameter laser beam, used with a laser repetition rate of $10 \mathrm{~Hz}$ and a laser power of $8 \mathrm{~J} \mathrm{~cm}^{-1}$. For all analyses, NIST614 was used for calibration of element sensitivity using the "Preferred Values" Ref 1 published on the GEOREM database. Calibration accuracy was checked by repeatedly analysing NIST610, NIST614, and BCR-2G as unknowns and 
comparing these to GEOREM values. Standards were analysed at the beginning, end, and periodically within each laser session. For data processing and calculation of concentrations, Glitter Software (GEMOC, Australia) was used to process the raw data files containing the signal intensity vs time data (the output from the Elan software). The overall process of the results and the subsequent geochemical models were conducted with the use of the software GCDkit (ver. 3). 
Table 1. The LA-ICP-MS analyses results of the Sicilian chert samples. The elements Al2O3, SiO2, TiO2 and Fe2O3 have their values in wt\%, while all elements are in part per million (ppm). BDL (Below Detection Limit) signifies a value for oxides or elements where the concentration is below the measured limit.

\begin{tabular}{|c|c|c|c|c|c|c|c|c|c|c|c|c|c|c|c|c|c|c|c|c|}
\hline Samples & Province & $\mathrm{Al}_{2} \mathrm{O}_{3}$ & $\mathrm{SiO}_{2}$ & $\mathrm{TiO}_{2}$ & $\mathrm{Mn}$ & $\mathrm{Fe}_{2} \mathrm{O}_{3}$ & La & $\mathrm{Ce}$ & $\mathrm{Pr}$ & Nd & Sm & $\mathrm{Eu}$ & Gd & Tb & Dy & Ho & $\mathrm{Er}$ & Tm & $\mathrm{Yb}$ & Lu \\
\hline S3 & Ragusa & 0.12 & 96.88 & 0.01 & 3.81 & 0.13 & 1.95 & 1.74 & 0.46 & 1.91 & 0.42 & 0.10 & 0.46 & 0.07 & 0.46 & 0.10 & 0.26 & 0.03 & 0.20 & 0.03 \\
\hline SD & Enna & 0.66 & 98.99 & 0.03 & 5.87 & 0.07 & 0.75 & 1.56 & 0.13 & 0.47 & 0.08 & 0.02 & 0.08 & 0.01 & 0.11 & 0.02 & 0.08 & 0.01 & 0.09 & 0.02 \\
\hline S5 & Enna & 0.18 & 98.85 & $<0.01$ & 6.27 & 0.05 & 0.37 & 0.22 & 0.10 & 0.43 & 0.11 & 0.03 & 0.12 & 0.02 & 0.11 & 0.02 & 0.07 & 0.01 & 0.06 & 0.01 \\
\hline S6a & Enna & 0.71 & 98.99 & 0.04 & 7.33 & 0.06 & 1.06 & 3.16 & 0.29 & 1.07 & 0.22 & 0.04 & 0.15 & 0.02 & 0.13 & 0.02 & 0.08 & 0.01 & 0.09 & 0.01 \\
\hline S6b & Enna & 5.26 & 87.98 & 0.23 & 677.26 & 4.00 & 11.29 & 28.38 & 2.24 & 7.33 & 1.15 & 0.23 & 0.83 & 0.12 & 0.76 & 0.18 & 0.50 & 0.08 & 0.59 & 0.09 \\
\hline S7 & Enna & 0.65 & 98.99 & 0.06 & 10.13 & 0.10 & 1.20 & 3.60 & 0.27 & 0.87 & 0.14 & 0.03 & 0.12 & 0.02 & 0.11 & 0.02 & 0.08 & 0.02 & 0.12 & 0.02 \\
\hline S10 & Enna & 0.19 & 98.99 & 0.01 & 2.42 & 0.02 & 0.16 & 0.25 & 0.05 & 0.21 & 0.04 & 0.01 & 0.04 & $<0.01$ & 0.04 & 0.01 & 0.02 & $<0.01$ & 0.01 & $<0.01$ \\
\hline S14 & Ragusa & 0.14 & 97.76 & 0.03 & 57.98 & 0.16 & 1.66 & 1.54 & 0.36 & 1.01 & 0.37 & 0.15 & 0.15 & 0.04 & 0.26 & 0.05 & 0.20 & 0.016 & 0.13 & 0.02 \\
\hline S15 & Ragusa & 0.26 & 98.79 & 0.02 & 11.00 & 0.24 & 1.78 & 1.37 & 0.35 & 1.53 & 0.31 & 0.08 & 0.38 & 0.06 & 0.41 & 0.09 & 0.25 & 0.03 & 0.22 & 0.03 \\
\hline S16 & Ragusa & 0.06 & 95.12 & $<0.01$ & 35.3 & 0.01 & 0.99 & 0.47 & 0.14 & 0.63 & 0.14 & 0.04 & 0.16 & 0.04 & 0.20 & 0.04 & 0.13 & 0.02 & 0.11 & 0.02 \\
\hline S17 & Ragusa & 0.09 & 98.68 & 0.01 & 8.66 & 0.06 & 0.45 & 0.39 & 0.08 & 0.32 & 0.06 & 0.01 & 0.06 & 0.01 & 0.06 & 0.01 & 0.0 & $<0.01$ & 0.03 & $<0.01$ \\
\hline S18 & Ragusa & 0.20 & 98.99 & 0.01 & 1.55 & 0.09 & 0.78 & 0.63 & 0.15 & 0.63 & 0.12 & 0.03 & 0.12 & 0.02 & 0.10 & 0.03 & 0.07 & 0.01 & 0.05 & 0.01 \\
\hline S19 & Ragusa & 0.26 & 98.99 & 0.07 & 142.52 & 0.57 & 4.86 & 3.29 & 0.86 & 4.24 & 1.51 & 0.23 & 1.60 & 0.16 & 0.74 & 0.18 & 0.68 & 0.07 & 1.67 & 0.07 \\
\hline S20 & Ragusa & 0.13 & 98.99 & 0.02 & 1.48 & 0.09 & 1.04 & 0.95 & 0.22 & 0.83 & 0.17 & 0.04 & 0.20 & 0.02 & 0.16 & 0.04 & 0.09 & 0.01 & 0.07 & 0.01 \\
\hline S21 & Ragusa & 0.16 & 98.99 & 0.02 & 0.53 & 0.02 & 0.95 & 0.90 & 0.20 & 0.83 & 0.17 & 0.04 & 0.17 & 0.02 & 0.14 & 0.03 & 0.06 & 0.01 & 0.06 & 0.01 \\
\hline$S 22 r$ & Palermo & 0.29 & 98.99 & 0.02 & 2.12 & 0.16 & 0.93 & 0.89 & 0.25 & 1.07 & 0.22 & 0.06 & 0.27 & 0.04 & 0.26 & 0.06 & 0.13 & 0.02 & 0.09 & 0.01 \\
\hline S22p & Palermo & 0.20 & 98.99 & $<0.01$ & 0.22 & $<0.01$ & 0.05 & 0.05 & 0.01 & 0.05 & 0.01 & $<0.01$ & 0.02 & $<0.01$ & 0.01 & $<0.01$ & 0.01 & $<0.01$ & 0.01 & $<0.01$ \\
\hline $\mathrm{S} 23$ & Palermo & 0.34 & 98.99 & 0.06 & 1.99 & 0.04 & 0.44 & 0.52 & 0.15 & 0.50 & 0.11 & 0.03 & 0.10 & 0.02 & 0.07 & 0.02 & 0.04 & $<0.01$ & 0.04 & 0.01 \\
\hline S24 & Palermo & 0.21 & 96.11 & 0.01 & 5.88 & 3.58 & 0.27 & 0.53 & 0.06 & 0.25 & 0.05 & 0.01 & 0.04 & 0.01 & 0.04 & 0.01 & 0.02 & $<0.01$ & 0.03 & $<0.01$ \\
\hline S25 & Palermo & 0.25 & 98.99 & 0.03 & 3.61 & 0.05 & 0.75 & 1.24 & 0.21 & 0.73 & 0.12 & 0.04 & 0.13 & 0.02 & 0.11 & 0.02 & 0.04 & 0.01 & 0.06 & 0.01 \\
\hline
\end{tabular}


Table 2. The LA-ICP-MS analyses results of the Xaghra Circle (BR) and Tać-Ċawla (TC) samples. The elements Al2O3, SiO2, TiO2 and Fe2O3 have their values in wt\%, while all elements are in part per million (ppm). The N/A (Not Applicable) is imported to indicate that the values of an element had RSD and \%REC outside the accepted values (RSD $<5$ and $95 \%<\%$ REC $<105 \%$ ). BDL (Below Detection Limit) signifies a value for oxides or elements where the concentration is below the measured limit.

\begin{tabular}{|c|c|c|c|c|c|c|c|c|c|c|c|c|c|c|c|c|c|c|c|c|}
\hline Samples & Site & $\mathrm{Al}_{2} \mathrm{O}_{3}$ & $\mathrm{SiO}_{2}$ & $\mathrm{TiO}_{2}$ & $\mathrm{Mn}$ & $\mathrm{Fe}_{2} \mathrm{O}_{3}$ & La & $\mathrm{Ce}$ & $\mathrm{Pr}$ & Nd & Sm & $\mathrm{Eu}$ & Gd & Tb & Dy & Ho & Er & Tm & $\mathrm{Yb}$ & Lu \\
\hline BR93/ S854/L897 & Circle & 0.48 & 98.75 & 0.04 & 30.31 & 0.34 & 2.37 & 2.72 & 0.55 & 2.38 & 0.49 & 0.10 & 0.56 & 0.08 & 0.50 & 0.11 & 0.27 & 0.03 & 0.21 & 0.03 \\
\hline BR88/ S110/L274 & Circle & 0.24 & 98.99 & 0.02 & 2.72 & 0.33 & 1.50 & 0.98 & 0.27 & 1.14 & 0.21 & 0.05 & 0.29 & 0.04 & 0.26 & 0.08 & 0.17 & 0.02 & 0.15 & 0.02 \\
\hline BR91/ S611/L712 & Circle & 0.28 & 98.99 & 0.03 & 6.85 & 0.22 & 3.42 & 1.66 & 0.55 & 2.22 & 0.43 & 0.11 & 0.64 & 0.08 & 0.65 & 0.12 & 0.36 & 0.05 & 0.36 & 0.04 \\
\hline BR89/ S291/L334 & Circle & 0.69 & 98.50 & 0.05 & 4.26 & 0.60 & 1.29 & 1.85 & 0.31 & 1.26 & 0.25 & 0.05 & 0.30 & 0.04 & 0.26 & 0.05 & 0.13 & 0.02 & 0.12 & 0.02 \\
\hline BR93/S843/L41 & Circle & 0.28 & 98.99 & 0.02 & 3.15 & 0.09 & 0.40 & 0.66 & 0.08 & 0.42 & 0.08 & 0.01 & 0.08 & 0.01 & 0.06 & 0.01 & 0.03 & 0.01 & 0.05 & 0.01 \\
\hline BR89/ S395/L449 & Circle & 0.20 & 98.99 & 0.01 & 2.23 & 0.08 & 0.29 & 0.46 & 0.07 & 0.23 & 0.05 & 0.02 & 0.04 & 0.01 & 0.04 & 0.01 & 0.03 & 0.00 & 0.02 & 0.01 \\
\hline BR91/ S564/L662 & Circle & 0.25 & 98.99 & 0.01 & 0.77 & 0.14 & 1.29 & 0.90 & 0.26 & 1.24 & 0.23 & 0.05 & 0.31 & 0.04 & 0.26 & 0.06 & 0.14 & 0.01 & 0.11 & 0.02 \\
\hline BR91/ S745/L845 & Circle & 0.06 & 97.77 & $<0.01$ & 1.21 & 0.02 & 0.55 & 0.58 & 0.13 & 0.53 & 0.10 & 0.03 & 0.11 & 0.01 & 0.15 & 0.03 & 0.04 & 0.01 & 0.02 & 0.01 \\
\hline BR91/S1142/L1279 & Circle & 0.17 & 98.07 & 0.01 & 2.29 & 0.05 & 0.50 & 0.60 & 0.10 & 0.36 & 0.08 & 0.02 & 0.10 & 0.01 & 0.09 & 0.02 & 0.04 & 0.00 & 0.05 & 0.01 \\
\hline BR91/L662/S566 & Circle & 1.61 & 62.04 & 0.10 & 39.7 & 0.44 & 5.25 & 10.40 & 1.17 & 5.27 & 1.35 & 0.22 & 0.87 & 0.13 & 0.84 & 0.18 & 0.52 & 0.07 & 0.43 & 0.08 \\
\hline TCC14/S252/L179 & Tać-Ċawla & 0.46 & 98.42 & 0.03 & 10.94 & 0.50 & 4.72 & 5.38 & 1.24 & 5.01 & 1.04 & 0.19 & 0.86 & 0.11 & 0.59 & 0.10 & 0.24 & 0.04 & 0.23 & 0.03 \\
\hline TCC14/S101/L85 & Tać-Ċawla & 0.44 & 98.83 & 0.03 & 8.99 & 0.25 & 3.98 & 2.93 & 0.80 & 3.61 & 0.78 & 0.20 & 0.92 & 0.13 & 0.91 & 0.20 & 0.58 & 0.08 & 0.46 & 0.07 \\
\hline TCC14/S275/L208 & Tać-Ċawla & 0.44 & 98.84 & 0.03 & 54.41 & 0.46 & 1.16 & 1.38 & 0.16 & 0.72 & 0.12 & 0.03 & 0.13 & 0.02 & 0.11 & 0.02 & 0.06 & 0.01 & 0.07 & 0.01 \\
\hline TCC14/S193/L69 & Tać-Ċawla & 1.11 & 97.96 & 0.03 & 15.30 & 0.49 & 0.62 & 1.31 & 0.15 & 0.35 & BDL & 0.05 & 0.06 & 0.00 & 0.15 & 0.02 & 0.05 & 0.01 & 0.10 & 0.01 \\
\hline TCC14/S144 & Tać-Ċawla & 0.48 & 98.65 & 0.05 & 5.16 & 0.47 & 0.80 & 1.28 & 0.23 & 0.95 & 0.21 & 0.03 & 0.18 & 0.03 & 0.14 & 0.04 & 0.08 & 0.01 & 0.12 & 0.02 \\
\hline TCC14/ S416/L178 & Tać-Ċawla & 0.35 & 97.89 & 0.03 & 4.48 & 0.20 & 1.00 & 1.25 & 0.26 & 1.05 & 0.23 & 0.05 & 0.26 & 0.03 & 0.20 & 0.04 & 0.11 & 0.01 & 0.11 & 0.01 \\
\hline TCC14/S577/L131 & Tać-Ċawla & 0.54 & 98.99 & 0.03 & 3.62 & 0.12 & 1.17 & 1.79 & 0.33 & 1.23 & 0.28 & 0.05 & 0.46 & 0.05 & 0.43 & 0.07 & 0.18 & 0.03 & 0.15 & 0.04 \\
\hline TCC14/S162/L155 & Tać-Ċawla & 0.63 & 97.66 & 0.09 & 93.64 & 0.60 & 1.08 & 3.36 & 0.46 & 1.17 & 0.12 & 0.04 & 0.15 & 0.02 & 0.16 & 0.05 & 0.07 & 0.01 & 0.15 & 0.01 \\
\hline TCC14/S103/L85 & Tać-Ċawla & 0.33 & 98.90 & 0.02 & 4.24 & 0.35 & 9.51 & 7.49 & 1.91 & 8.95 & 2.10 & 0.42 & 2.81 & 0.35 & 2.21 & 0.51 & 1.30 & 0.18 & 0.90 & 0.12 \\
\hline TCC14/S316B/L63 & Tać-Ċawla & 0.24 & 94.09 & 0.02 & 8.72 & 0.15 & 1.96 & 2.51 & 0.50 & 2.14 & 0.50 & 0.11 & 0.54 & 0.07 & 0.46 & 0.08 & 0.20 & 0.03 & 0.16 & 0.02 \\
\hline TCC14/S460/L273 & Tać-Ċawla & 0.38 & 98.51 & 0.05 & 18.71 & 0.38 & 4.41 & 2.90 & 0.69 & 2.92 & 0.61 & 0.14 & 0.81 & 0.10 & 0.72 & 0.16 & 0.53 & 0.09 & 0.48 & 0.07 \\
\hline TCC14/S176/L100 & Tać-Ċawla & 0.58 & 81.88 & 0.12 & 58.66 & 0.99 & 5.23 & 9.90 & 1.03 & 3.72 & 0.95 & 0.22 & 1.20 & 0.10 & 0.61 & 0.13 & 0.75 & 0.04 & 0.32 & 0.04 \\
\hline TCC14/S32B/L30 & Tać-Ċawla & 0.14 & 97.81 & 0.01 & 3.80 & 0.09 & 0.73 & 1.42 & 0.18 & 0.71 & 0.14 & 0.03 & 0.16 & 0.02 & 0.13 & 0.02 & 0.08 & 0.01 & 0.05 & 0.01 \\
\hline
\end{tabular}




\begin{tabular}{|c|c|c|c|c|c|c|c|c|c|c|c|c|c|c|c|c|c|c|c|c|}
\hline TCC14/S513/L272 & Tać-Ċawla & 0.63 & 21.33 & 0.03 & 28.80 & 0.22 & 3.21 & 5.30 & 0.74 & N/A & N/A & N/A & 0.60 & N/A & N/A & 0.11 & N/A & N/A & 0.31 & $\mathrm{~N} / \mathrm{A}$ \\
\hline TCC14/L30/S37 & Tać-Ċawla & 0.19 & 47.92 & $<0.01$ & 3.60 & 0.02 & 0.72 & 0.30 & 0.15 & $\mathrm{~N} / \mathrm{A}$ & N/A & N/A & N/A & N/A & N/A & 0.06 & N/A & N/A & N/A & $\mathrm{N} / \mathrm{A}$ \\
\hline
\end{tabular}




\section{Results}

\subsection{Macroscopy}

\subsubsection{Chert sources of Sicily}

Chert formations are reported in all the main geological rock-groups of Sicily (e.g. Carbone et al., 1990; Lentini, 1984). The fieldwork survey (conducted by Chatzimpaloglou in 2017) used the baseline provided from the literature (Catalano et al. 1984, 1989; Lentini, 1984; Lentini et al. 1995) and focused on regions with the most important and representative chert outcrops of the island. The first region is the Ragusa province in southeast Sicily, which solely presents formations of the Hyblean Plateau unit (Fig. 4) that spans from Cretaceous (Campanian) to Quaternary. The next location is Enna province in northeast Sicily that is dominated by the "European group" spanning from Triassic to Cretaceous (Fig. 4). The last region is Palermo province, which in comparison to Enna province, presents all the formations of the "European group" (Fig. 5). In addition, it has exposures of Cretaceous-Jurassic volcanic activity which may also have chert sources.

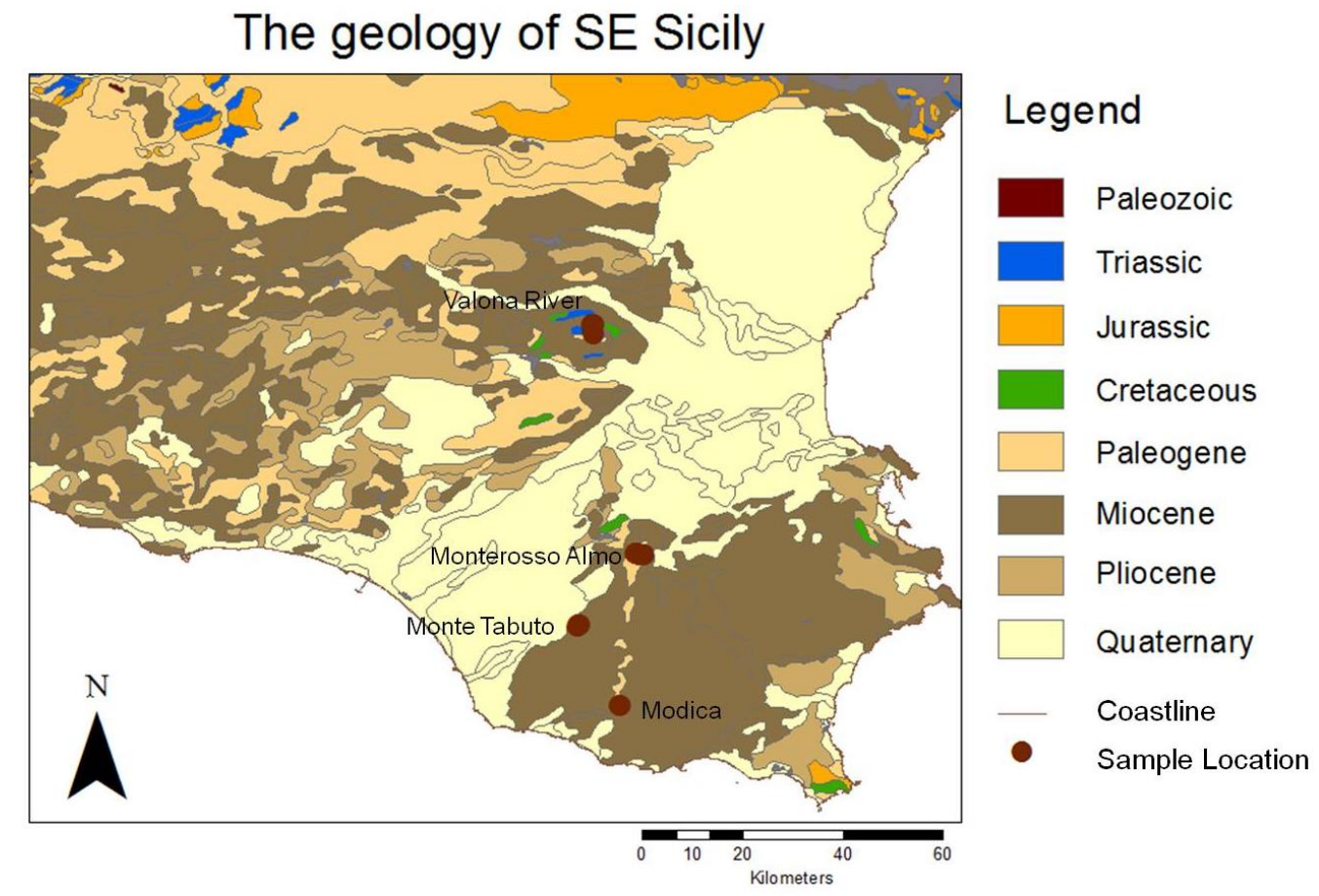

Figure 4. Modified geological map of East Sicily. The formations are divided based on their age. The map includes the sample locations from Ragusa and Enna province. 


\section{The geology of West Sicily}

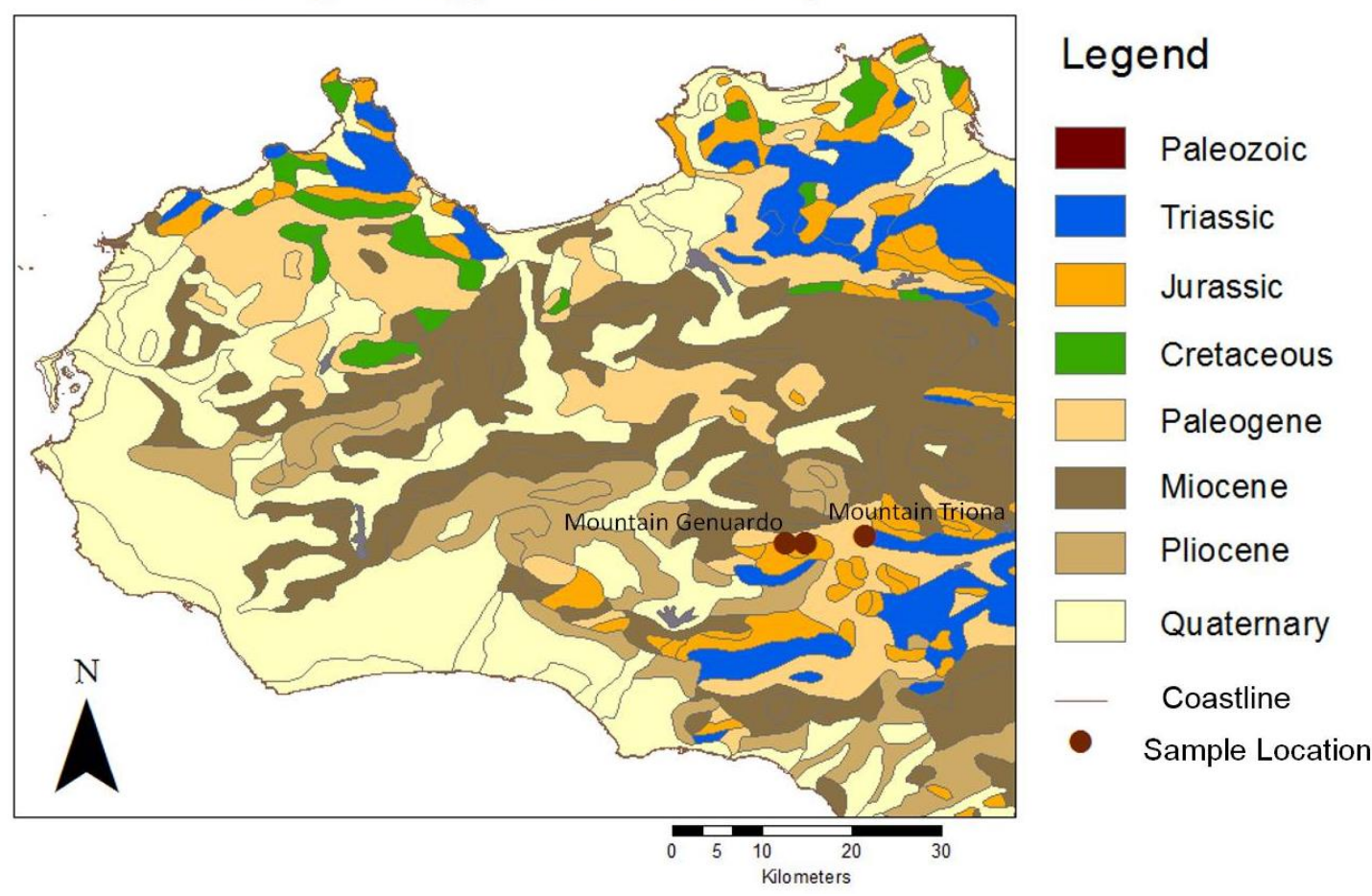

Figure 5. Modified geological map of West Sicily. The formations are divided based on their age. The map includes the sample locations from Palermo province.

\subsubsection{Province of Ragusa}

This area is particularly important for this research as it presents evidence of prehistoric mining activity and it may be a location from where chert material was exported to Malta (Vella, 2008). The first chert sources were recorded at Monte Tabuto area and characterised as brown to black in colour, dull and opaque. The next stop was south of Modica Town, which presented small nodular cherts, and occasionally formed beds of 5 to $10 \mathrm{~cm}$ in thickness. They are described as fine-grained, translucent and present dark brownish (5YR 2/1) colours (sample S3). Although Monte Tabuto and Modica are inside a region with an archaeological interest, they presented very restricted chert outcrops and their exploitation was not confirmed.

The last stop was near the town of Monterosso Almo which is located at the northern part of the province. This area presents abundant chert sources which extend, in the geological time scale, from Cretaceous to Quaternary. Most of the outcrops are within the Armerillo Formation, mainly in bedded form (2-10 cm in thickness). They are heterogenic, fine-grained and semi-translucent, while they vary from greyish (N6) (samples S13 and S15) and brownish (5YR 2/2) (sample S14) to black colours (samples S17). The higher parts of this formation (Paleocene to Eocene) includes chert outcrops as lenses but mostly as huge (>12 cm in diameter) and irregular nodules (Fig. 6). They retain the same 
macroscopic characteristics except for their colours, which in this case is brownish black (5YR 2/1) (sample S18) to orange (sample S20 and S21). Overlaying the Amerillo Formation, a Pliocene brecciated formation has been reported. The fieldwork found that some of these breccias were actually nodular cherts, which could easily be extracted with the use of a lever. They are heterogenic, fine-grained, semi-translucent and black in colour (sample S19).

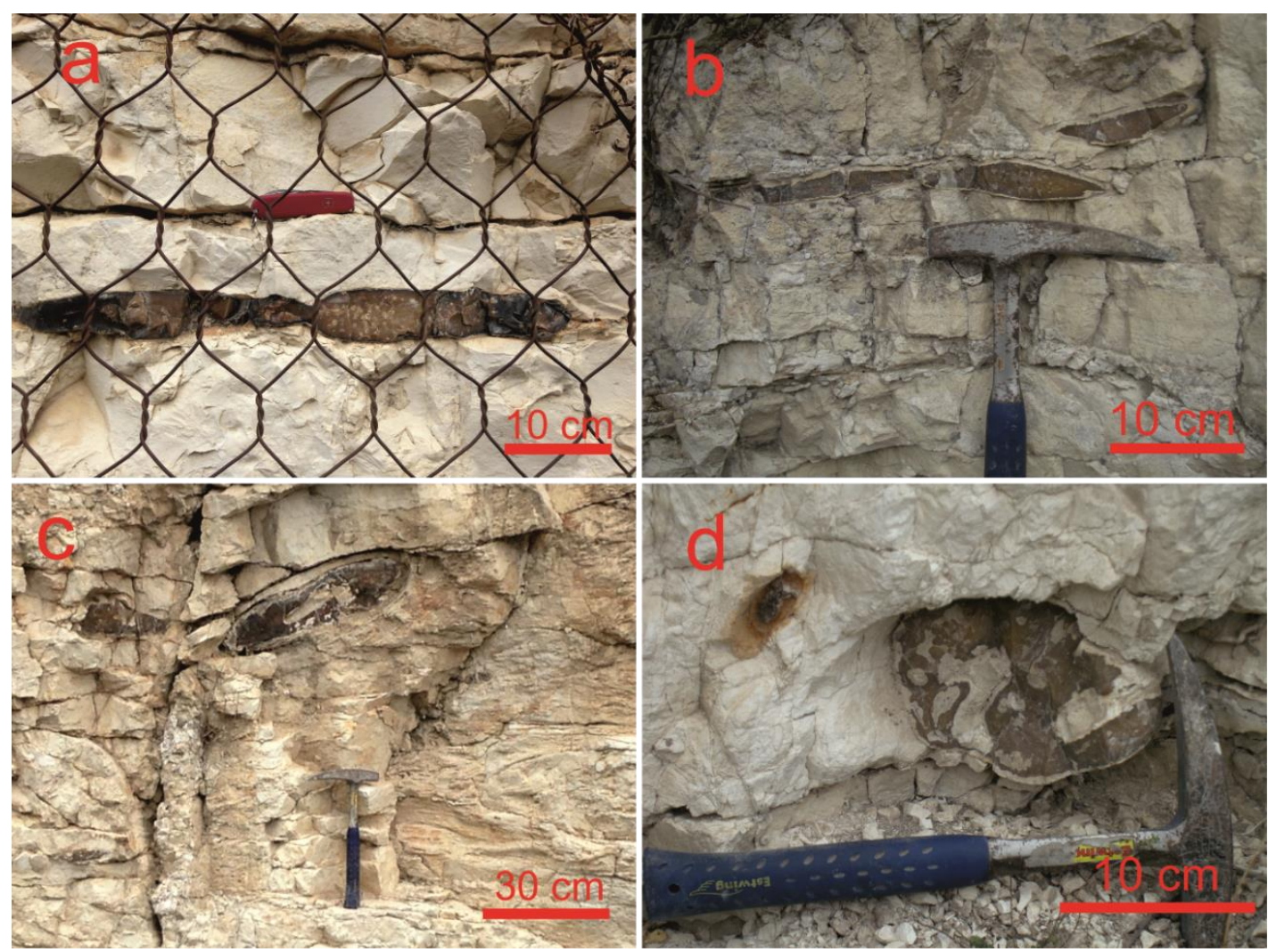

Figure 6. Representative chert sources from Monterosso Almo, which are found within the limestones of the Hyblean Plateau unit ( $a$ to d): (a) black to brownish chert; (b) chert lenses outcrops; (c) huge and irregular nodules and (d) huge nodular chert with chalky residues.

\subsubsection{Province of Enna}

The chert sources in this province are found within the formations of the Monte Judica unit, which spans from Triassic to Miocene (Carbone et al., 1990). The Triassic limestones were examined in two different locations and presented two different type of chert sources. The first (Contrada Lavina) included fragmented nodular cherts of different sizes and shapes, and two representative samples were collected (S4 and S5). The second (Monte Santo) presented well-developed, black and bedded chert (Figs. 7c and d), and three representative samples were collected (S9, S10, S11).

Impressive were the findings at the Valona River riverbed, where exposures of the Radiolarian formation (Jurassic - Cretaceous) were found (Figs. 7a and b). The formation had huge exposures and 
expanded to several metres high. It consisted of a sequence of radiolarian beds with different thicknesses $(3-12 \mathrm{~cm})$, with colours varying from red to green. Although the beds present variations, they are mainly homogenic, semi-translucent and shiny, and at this place three samples (S6, S7 and S8) were collected for further investigation.

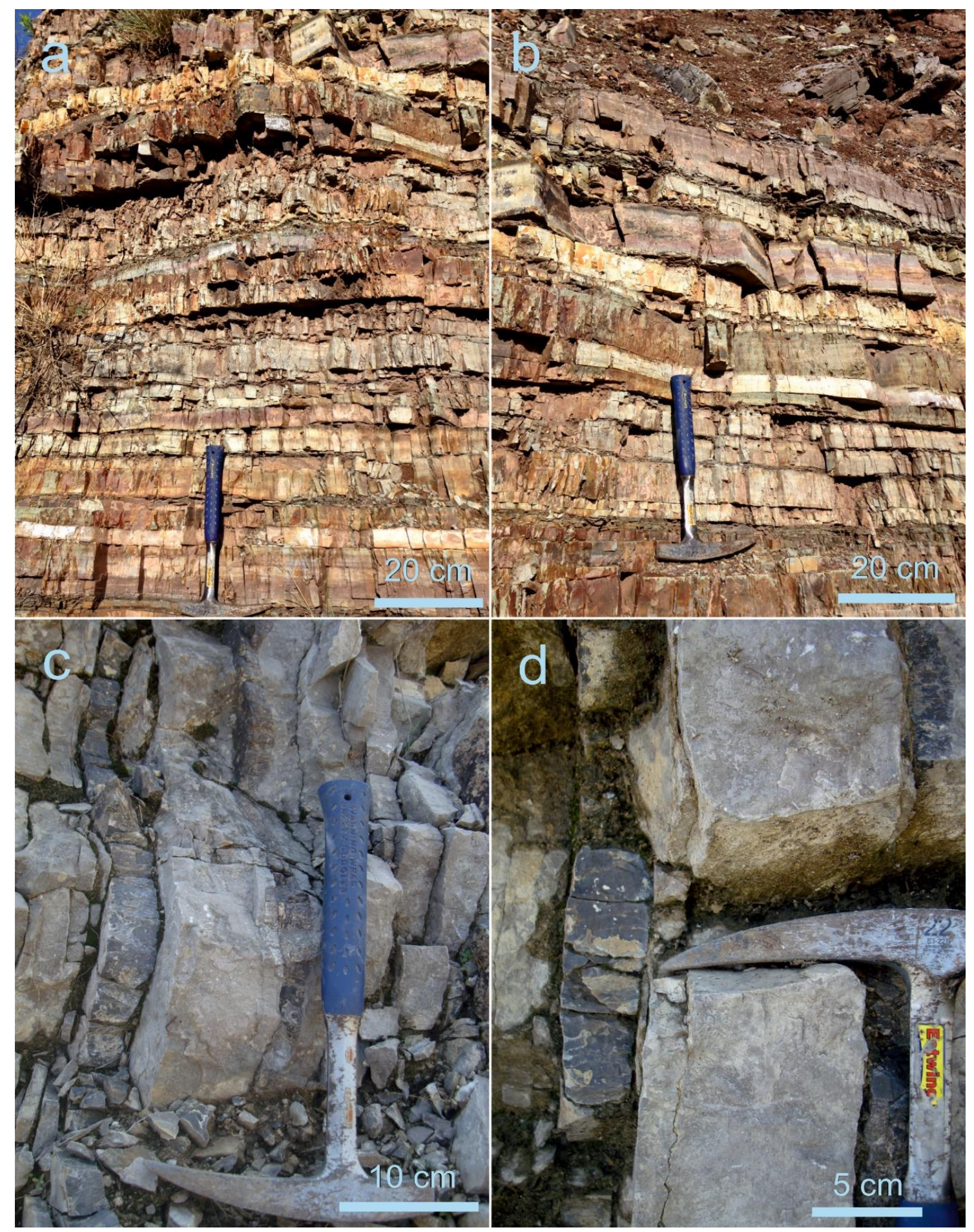

Figure 7. Representative chert sources from Enna province (a to d): (a) and (b) Illustrate the length of the Radiolarian formation along the riverbeds of Valona River; (c) and (d) show the black bedded chert outcrops at Monte Santo. 


\subsubsection{Province of Palermo}

This region presents formations that are related again to the "European group" which in this region belongs to the Bacino Sicano unit (Catalano 2004; Di Stefano et al. 1992; Di Stefano et al. 2013). The oldest chert outcrops were found inside Triassic limestones and were investigated at Troina Mountain. These limestones are considered synchronous with ones in the Monte Judica unit (province of Enna). The cherts are small nodular or lenses outcrops, highly fragmented, with irregular shapes and very difficult to extract (Fig. 8a). They are similar to the ones found in Enna province, but some of the Palermo outcrops present an orange (5YR 5/2) colour (sample S22).

The research moved to the area around Genuardo Mountain, where other and more abundant chert sources were reported. The investigation found black bedded cherts (Fig. 8b) which were approximately 6-10 cm in thickness and within Jurassic limestone (sample S23). They are homogenic, dull, opaque and fine-grained. Chert sources were also found in the overlaying limestone formation (middle-upper Jurassic), but with different macroscopic characteristics. This formation is highly silicified and contains intercalations ofgreyish (N4) bedded chert (Fig. 8d). These cherts present a significant amount of carbonate residues and the beds are 4-6 cm in thickness (sample S25).

The last chert material, identified, has indications of a relationship with volcanic activity. It differed significantly from all other chert formations previously examined. Plenty of scattered pieces of a dense, heavy and solid yellowish chert (Fig. 8c) were found lying on agricultural fields. The macroscopic characteristics of these pieces suggests a relationship with the basaltic lavas which are recorded on the geological map (Di Stefano et al, 2013) of the region. The in situ examination of this outcrop was unsuccessful, but one of these scattered pieces (sample S24) was collected as evidence and for further laboratory research. 

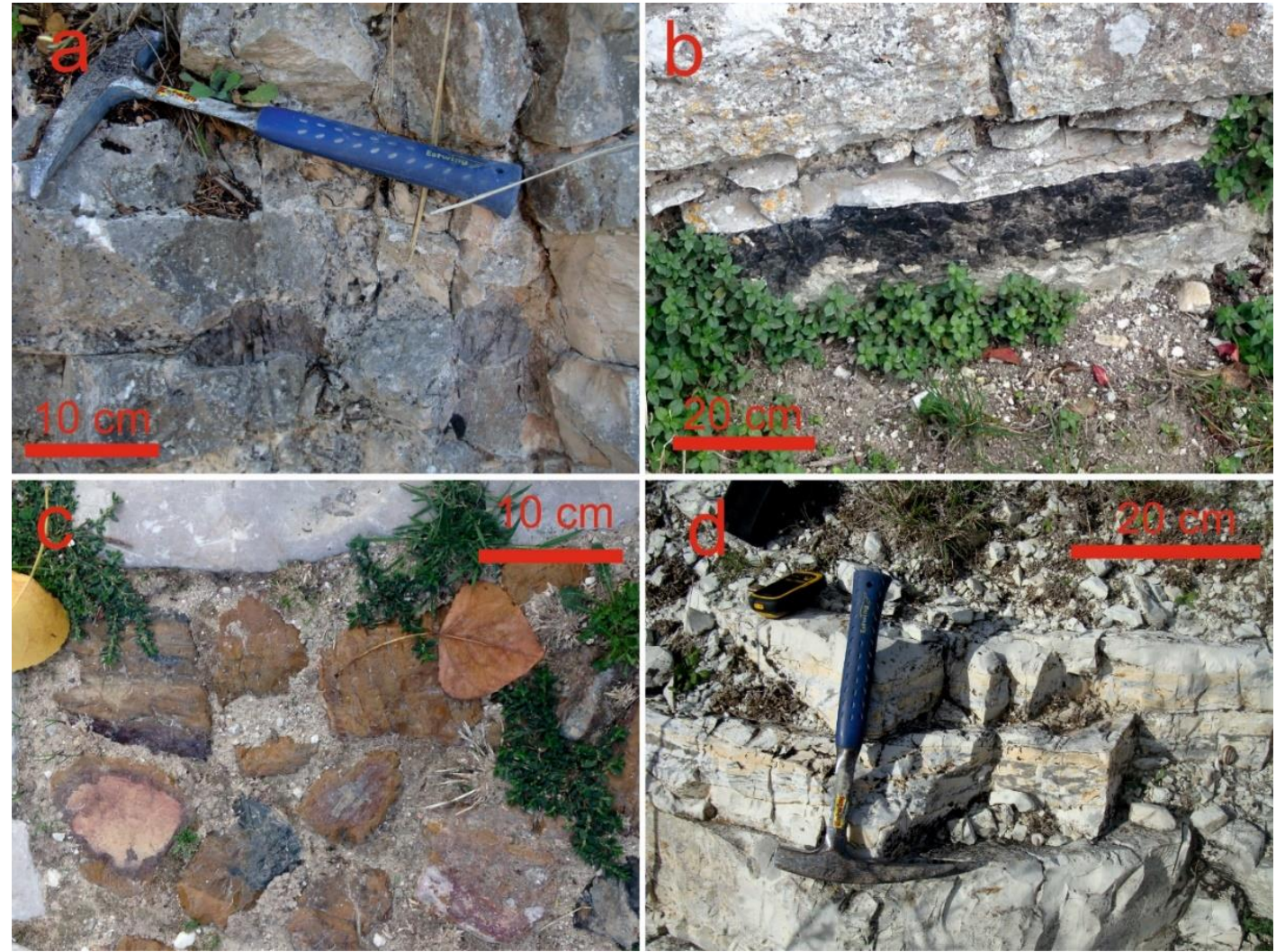

Figure 8. Representative chert sources from Palermo province (a to d): (a) fragmented nodular cherts within Triassic limestones found at Triona Mountain; (b) black bedded chert outcrop at the Genuardo Mountain; (c) pieces of the chert rocks possibly related with the volcanic activity and (d) greyish bedded cherts intercalated with a highly silicified limestone.

\subsubsection{Maltese chert sources}

It is considered useful at this stage to provide some information about the local chert material to allow a clear distinction between the raw materials of Malta and Sicily. It was well established from the literature (Pedley et al., 2002) that the chert outcrops are located in the middle Globigerina Limestone. The fieldwork on the Maltese islands further revealed that the cherts are found only on the western parts of Malta and Gozo. The investigation of both locations showed that the cherts generally share similar macroscopic characteristics and are in bedded or nodular form. They are finegrained, dull, opaque, with greyish ( $5 Y 3 / 2$ ) and olive-brown (5Y 4/4) colours and have a distinctive spotted feature.

\subsubsection{Chert Assemblages}

The investigation of the assemblages has revealed that the artefacts are made from multiple lithic sources and are not restricted just to chert rocks. First, the total number of the finds were recorded and then the lithics were divided into three categories: a) chert, b) obsidian and c) "other". The chert category includes chert and materials which are considered either chert cortex or highly silicified limestone. The "other" category includes mainly limestone pieces and those which due to their 
macroscopic characteristics cannot be placed within any of the other two categories. Subsequently, the macroscopic characteristics of the chert materials were recorded and representative samples from each assemblage were selected for further laboratory analyses.

\subsubsection{The Brochtorff-Xaghra Circle assemblage}

The assemblage of the Circle totaled 225 pieces and includes artefacts which are made from a variety of rock materials. Eight pieces are made from limestone, while one is made from calcite. Furthermore, there is a group of artefacts $(n=18)$ of an unknown rock source, but clearly not related to chert rocks. Finally, there are a few chert artefacts which are patinated. The latter have been excluded from further investigation as patina (white or coloured) alters their macroscopic characteristics and any interpretation will not be accurate.

Focusing on the chert members of the assemblage in terms of sources, they are divided mainly into three main groups (Fig. 9). The first group of artefacts is mainly characterized by brown colours (10YR 4/2,6/2 and 5YR 3/2), fine-grain size, and the absence of translucency (i.e. opaque) and shine (i.e. dull). The majority of the members of the assemblage are included in this group and are generally of greater size in comparison with artefacts of other chert materials (Fig. 9a).

Another important group included opaque, dull, spotted and grey coloured (e.g. 5Y 6/1) artefacts. The artefacts of this group are described as spotted (Crandell, 2006) because they presented irregular shapes of white spots on their surface (Fig. 9c). The characteristics of this group are compatible with the ones found in the Maltese chert formations. Additionally, the size of the artefacts of this group is substantial, but not on the same level as the ones in the first group.

The last group consists of small artefacts that exhibit a high level of translucency and similarities in lustre, texture and grain size (Fig. 9e). However, the diversity in colours (e.g. yellow, red and brown) and the fluctuation in the levels of translucency suggest that they are from different raw sources.

\subsubsection{Tac்-Ċawla assemblage}

The Tać-Cawla assemblage consists of 693 pieces in total of which 457 are chert, 111 obsidian and 125 "other" material. The examination suggests that the "other" material is mainly related to local limestone (possibly Coralline) and secondary calcite.

Focusing on the chert members of the assemblage, they are divided into three main groups in terms of sources (Fig. 9). The first group is again identified by their brown colour shades (10YR 4/2, $6 / 2$ and $2 / 2$ ) and the absence of translucency and shine. This type of material is used for a variety of artefacts and found in different shapes and sizes (Fig. 9b). The characteristics of this group are very similar with the equivalent first group of the Circle assemblage. Moreover, an artefact from the Circle 
(i.e. BR94/S1142/L1279) and a member of this group (i.e. S176/S100) most likely have a common origin.

The second group includes artefacts with macroscopic features similar to the local chert sources (Fig. 9d). They are mainly identified from the characteristic brownish colour shades (e.g. 5Y 4/4) and the white spots on their surface. In comparison with the first assemblage, they are fewer in number and present less variety. The final group includes all the multi-coloured and highly translucent artefacts that relate neither to the local resources nor to artefacts of the first group (Fig. 9f). Although the members of this group present a variety of colours, they are all highly translucent, shiny and finegrained. It is the fluctuation in these characteristics which does not allow any safe conclusion to be drawn on their sources at this stage.

Nevertheless, it is possible to record the similarities between the artefacts of the Circle and TacCawla, and the chert formations of Sicily. Indeed, there are some yellowish artefacts (e.g. TCC14/S103/L85) that have many similarities with artefacts from the Circle assemblage (e.g. BR89/S291/L334). In addition, there is one artefact from Tać-Cawla (TCC14/S416/L178) and one from the Circle (i.e. BR91/S611/L712) that present very similar macroscopic characteristics with some outcrops in southeastern Sicily (S18 and S19). 


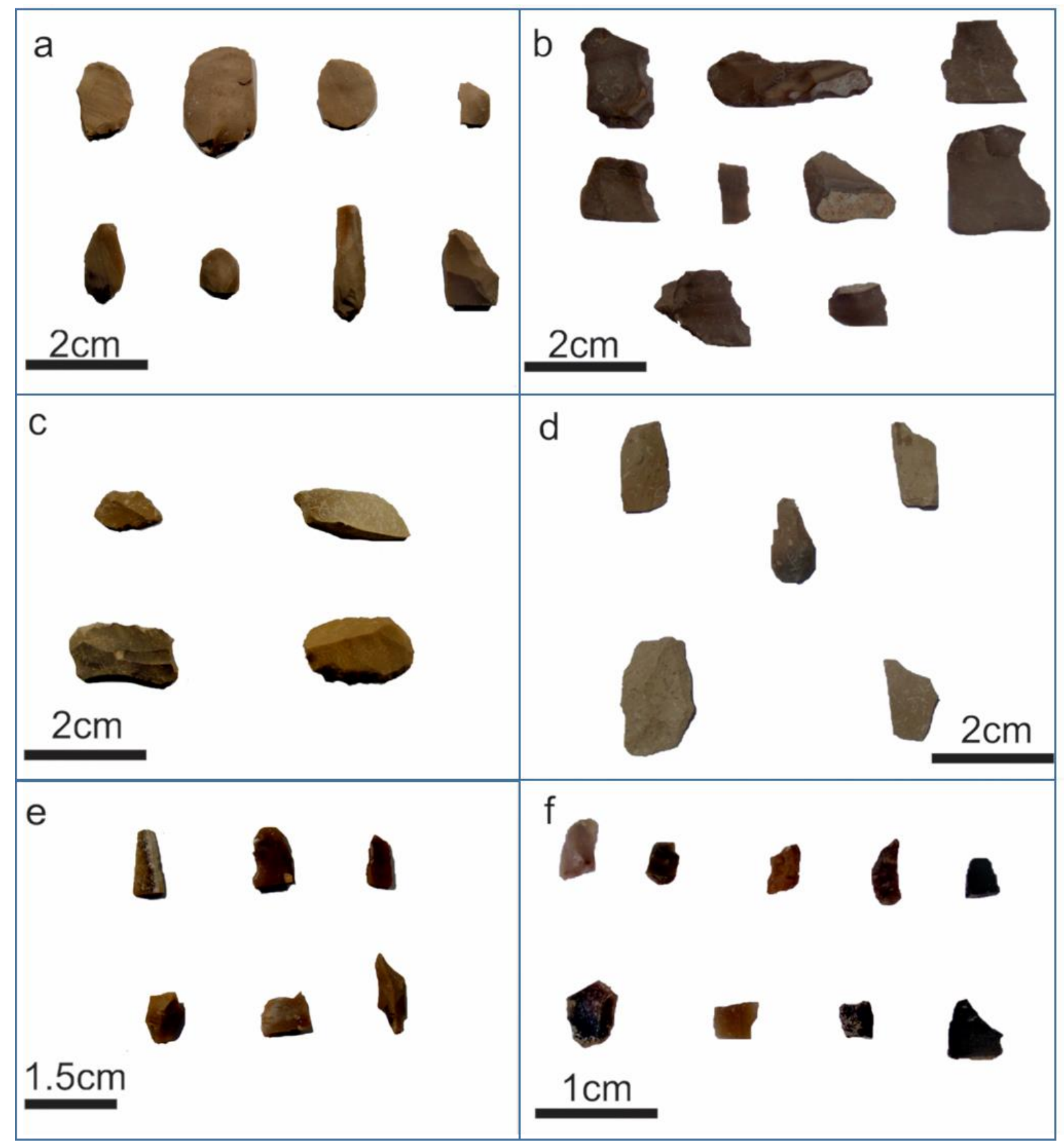

Figure 9. Representative artefacts of the different chert varieties found in the assemblages of Circle $(a, c$ and e) and TaćĊawla (b, d and f): (a) and (b) artefacts that belongs to the first group; (c) and (d) artefacts that belongs to the second group; (e) and (f) artefacts that belongs to the third group.

\subsection{Chemical}

\subsubsection{Sicilian chert sources}

Previous studies (e.g. Junguo et al., 2011) demonstrate a ternary model which combines the concentrations of $\mathrm{Fe}, \mathrm{Al}$ and $\mathrm{Mn}$ to identify the main source of cherts. Plotting this model with the rock samples of Sicily (Fig. 10a) demonstrates that most of the Sicilian (75\%) are related to biogenic sedimentation. $10 \%(n=2)$ of the Sicilian samples are related to hydrothermal sedimentation, while 
one ( $\mathrm{S} 22 \mathrm{p}$ ) has high extremely concentrations of $\mathrm{Al}$ and is placed outside the areas of the two types of sedimentation at the very top of the ternary diagram. The literature (e.g. Murray, 1994) further suggests that the concentrations of $\mathrm{Fe}, \mathrm{Al}$ and $\mathrm{Ti}$ can be chemical criteria for the depositional environment of the sedimentary rocks. This theory has created a model which uses the ratio $\mathrm{Fe} / \mathrm{Ti}$ on the $\mathrm{y}$-axis and the ratio of $\mathrm{Al} /(\mathrm{Al}+\mathrm{Fe})$ to distinguish between three distinctive depositional environments (Murray, 1994). Plotting the rock samples on this model (Fig. 10b) demonstrates that the Sicilian cherts are widespread and can be related to all three environment types.

The literature has shown (e.g. Masuda 1977; Murray, 1994; Junguo et al., 2011) that the relative fractionations of the rare earth elements (REES) are a good geochemical tracer for studying the chert origin and palaeoenvironment as well as the oxidation and reduction conditions. In comparison with the major and trace elements, the REEs are not affected by the age of the rock or the tectonic history and are independent of diagenetic modification (Murray et al, 1992). The focus on these elements falls on their normalised patterns which can provide a holistic perspective of their concentration and the relationship between them (Fig. 11). The values of the REEs are always normalised with suitable rock standards to avoid unnormal fluctuation of elemental abundances. Based on the type of rocks examined in this study, the World Average Shale standard (Piper, 1974) is selected.

Most of the Sicilian chert samples $(n=18)$ have low concentrations of REEs $\left(10^{-2}\right)$, while two chert samples (S6a and S19) are more enriched and show higher quantities of REE's (Figs. 11a and b). The majority of the Sicilian samples (65\%) present a significant depletion of $\mathrm{Ce}$ and minor depletion of $\mathrm{Tb}$ in contrast with the other RREs. The only exceptions are the chert samples (S6a, S6b and S7) from the Radiolarian formation (Fig. 11b), which are relatively enriched in Ce. Finally, one sample from west Sicily (i.e. S24) presents an almost linear REE pattern (Fig. 11c). 

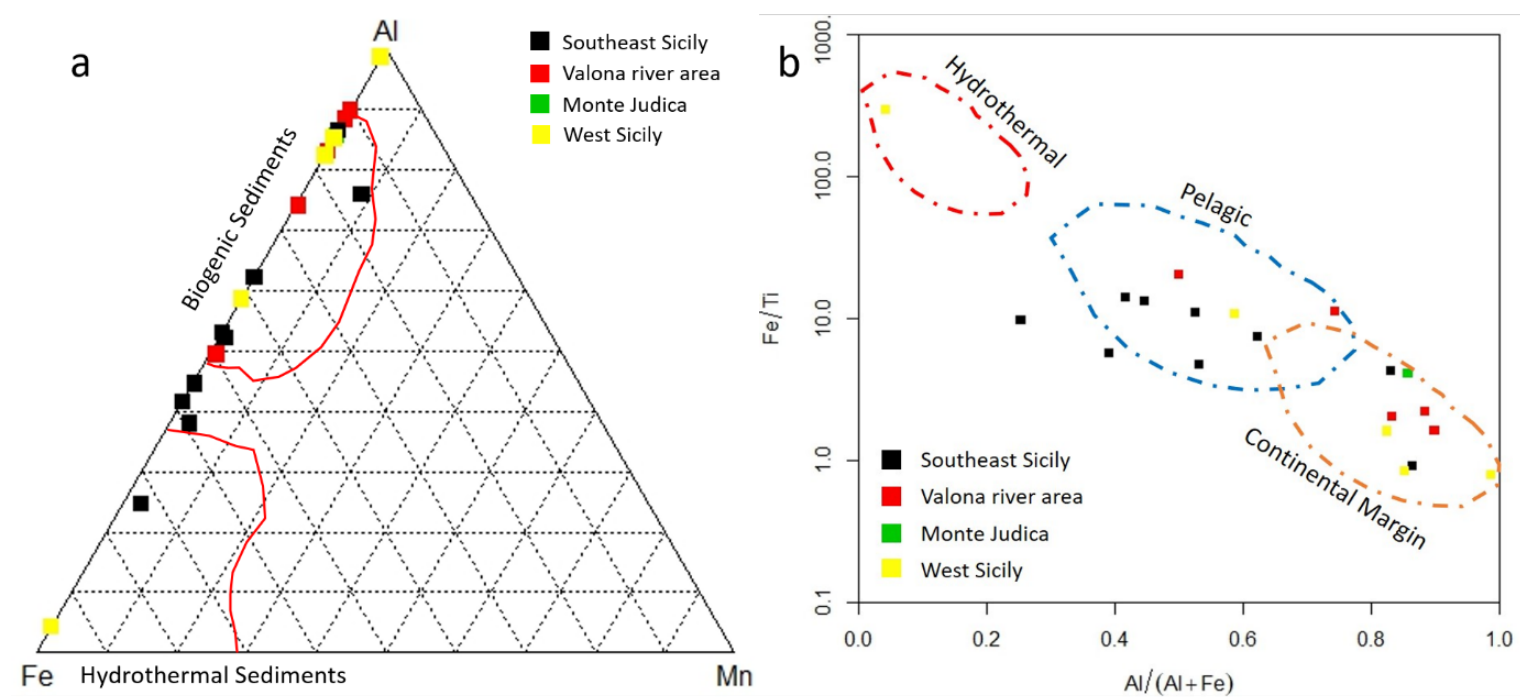

Figure 10.Geochemical models with the Sicilian chert sources ( $a$ and $b$ ): (a) ternary diagram examining the type of the sediments related to rock samples and (b) binary diagram examining the type of depositional environment of the rock samples. The line demarcations have followed the suggestion of the literature (Junguo et al. 2011, Murray et al, 1994).
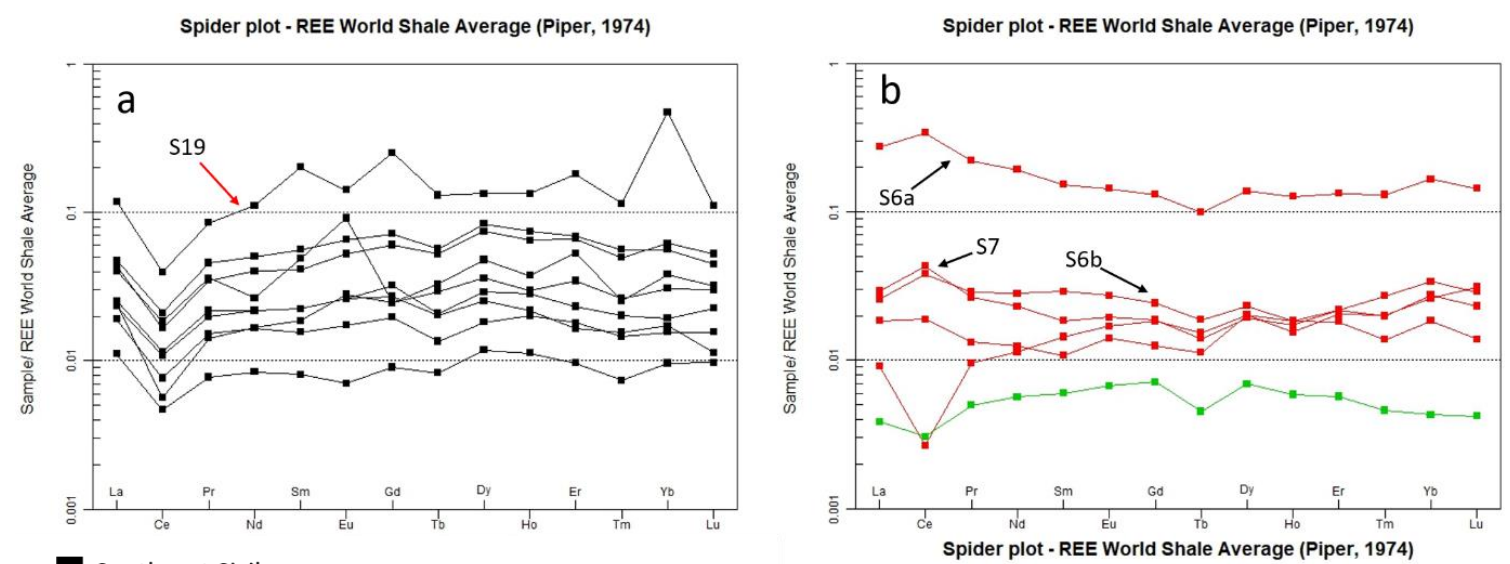

Southeast Sicily

Valona river area

Monte Judica

West Sicily

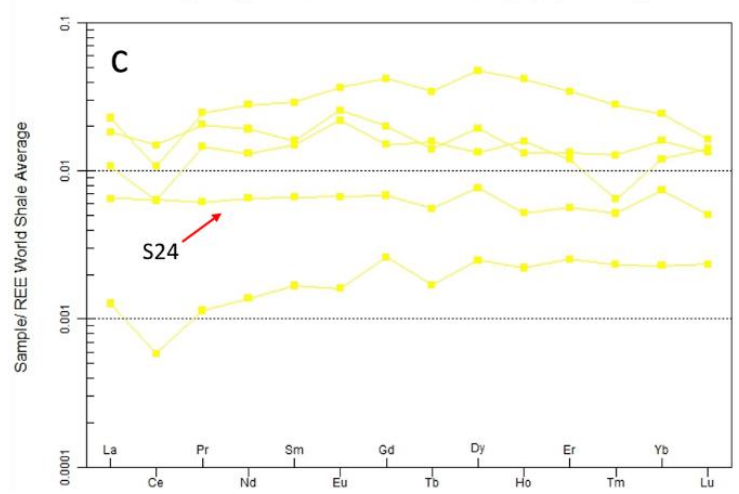

Figure 11.The normalised patterns of rare earth elements of the Sicilian chert samples (a to c): (a) the REE normalised pattern of chert sources in Ragusa province; (b) the REE normalised pattern of the chert sources in Enna province and (c) the REE normalised pattern of the chert sources in Palermo province. 


\subsubsection{Chert artefacts}

The geochemical results of the artefacts from Malta follow the theoretical background presented above (Figs. 12 and 13). The research on the chert artefacts starts from the triangle model, which combines the concentrations of $\mathrm{Fe}, \mathrm{Al}$ and $\mathrm{Mn}$ to identify their type sedimentation (i.e. hydrothermal or biogenic). The majority of the examined artefacts of the assemblages $(n=20 ; 74 \%)$ are related to biogenic sedimentation (Figs. 12a and 13a). Nevertheless, there is one artefact from the Circle and one from the Tać-Ċawla $(n=1)$ assemblages that fall within the hydrothermal sedimentation region. Additionally, there are a few artefacts from Tać-Ċawla $(n=5)$ that cannot be clearly correlated with either a biogenic or hydrothermal sedimentation.

The second step is to use the concentrations of $\mathrm{Fe}, \mathrm{Al}$ and $\mathrm{Ti}$ in a binary model and identify the depositional environment of the chert artefacts (Figs. $12 \mathrm{~b}$ and 13b). The model demonstrates that most of the samples from the Circle (60\%) and Tać-Ċawla (74\%) are in a region related to a pelagic environment. There is only one sample in the assemblages of Tać-Cawla (TCC14/S577/L131) that was clearly related to a continental margin environment. In addition, there are two samples of the same assemblage that fall outside the regions of these three types of environment.

The last step of the research involving the rare earth elements (REE) is the examination of the normalised patterns of these elements which can further contribute to connecting artefacts with sources (Fig. 14). The samples from the Circle assemblage, according to their pattern, are divided into three groups (Fig. 14a). The first group includes one artefact (yellow arrow) which has normalised REE concentrations at the same level, except the Tb element that presents a small depletion. The second group has lower normalised concentrations $\left(<10^{-1}\right.$ level) than the first and presents more fluctuating patterns. They have an important depletion of $\mathrm{Ce}$ and minor of $\mathrm{Tb}$, and their patterns are very similar. Furthermore, they are enriched on gadolinium (Gb) and dysprosium (Dy), which are characteristics not reported to the other groups. The third group has the lowest concentrations of REEs $\left(10^{-2}\right.$ level) and their patterns greatly fluctuate, which does not allow the recording of further characteristics.

The samples from Tać-Cawla exhibit patterns that are less spread in the diagram (Fig. 14b), in comparison with the previous assemblage. They all have a noticeable depletion of $\mathrm{Ce}$, an enrichment of $\mathrm{Gb}$ and a minor depletion of $\mathrm{Tb}$. The majority of the samples (54\%) have a similar pattern, but deviations in different elements have been reported. 

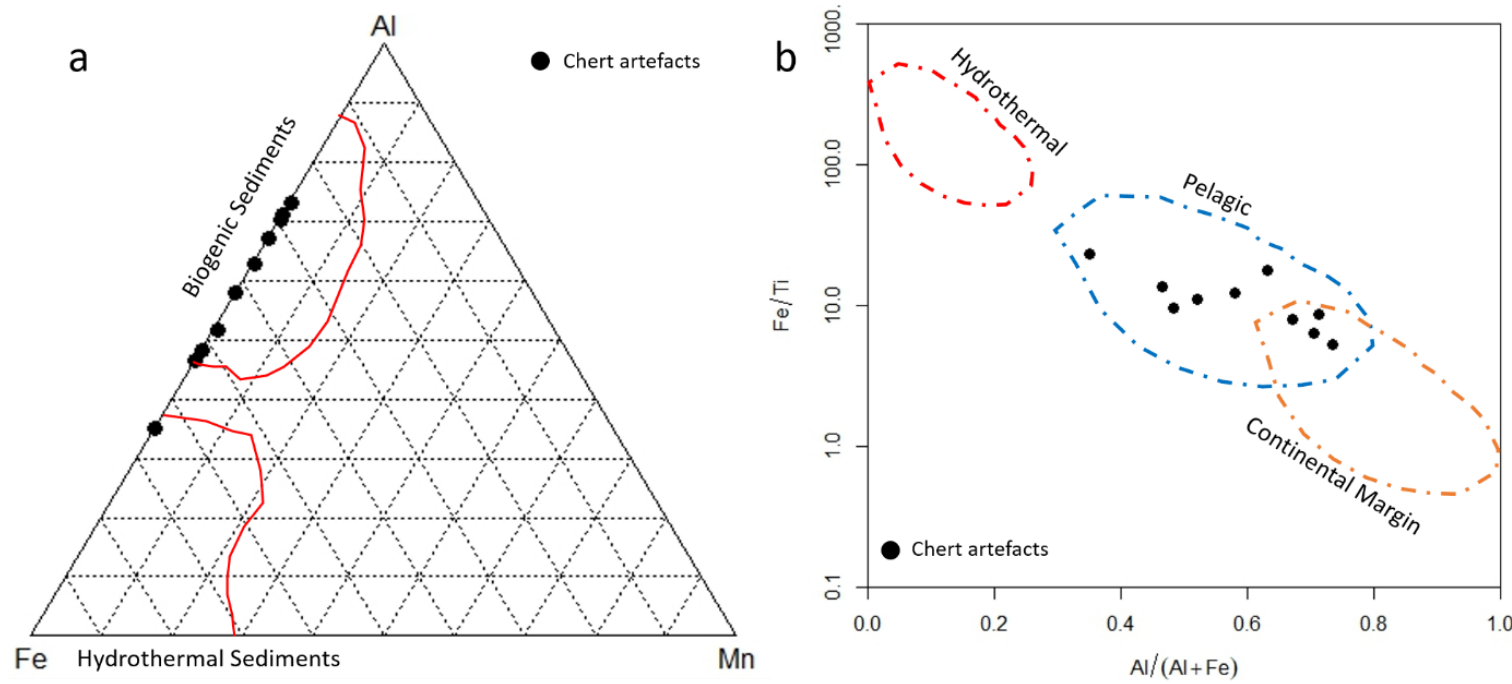

Figure 12. Geochemical models with the chert artefacts from the Circle assemblage ( $a$ and $b$ ): (a) ternary diagram examining the type of the sediments related to artefact samples and (b) binary diagram examining the type of depositional environment of the artefact samples. The line demarcations have followed the suggestion of the literature (Junguo et al. 2011, Murray et al, 1994).
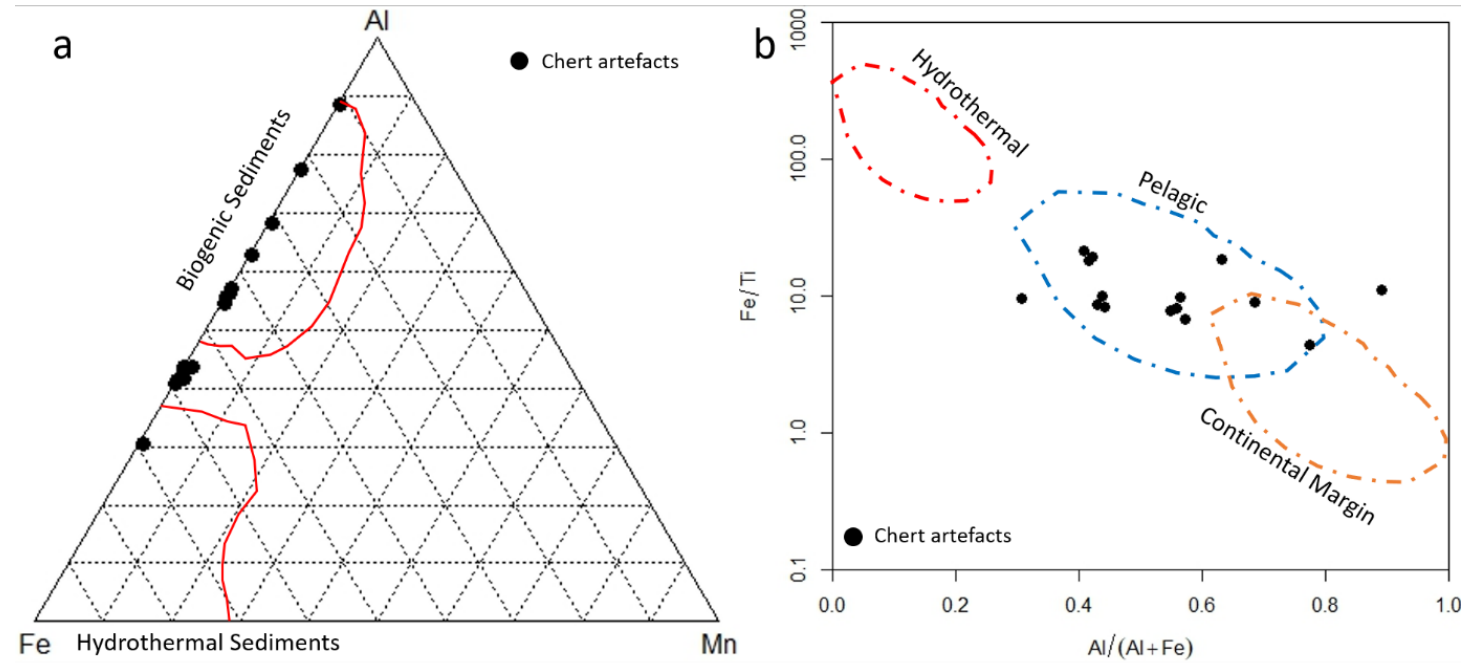

Figure 13. Geochemical models with the chert artefacts from the Tać-Ċawla assemblage ( $a$ and $b$ ): (a) ternary diagram examining the type of the sediments related to artefact samples and (b) binary diagram examining the type of depositional environment of the artefact samples. The line demarcations have followed the suggestion of the literature (Junguo et al. 2011, Murray et al, 1994). 

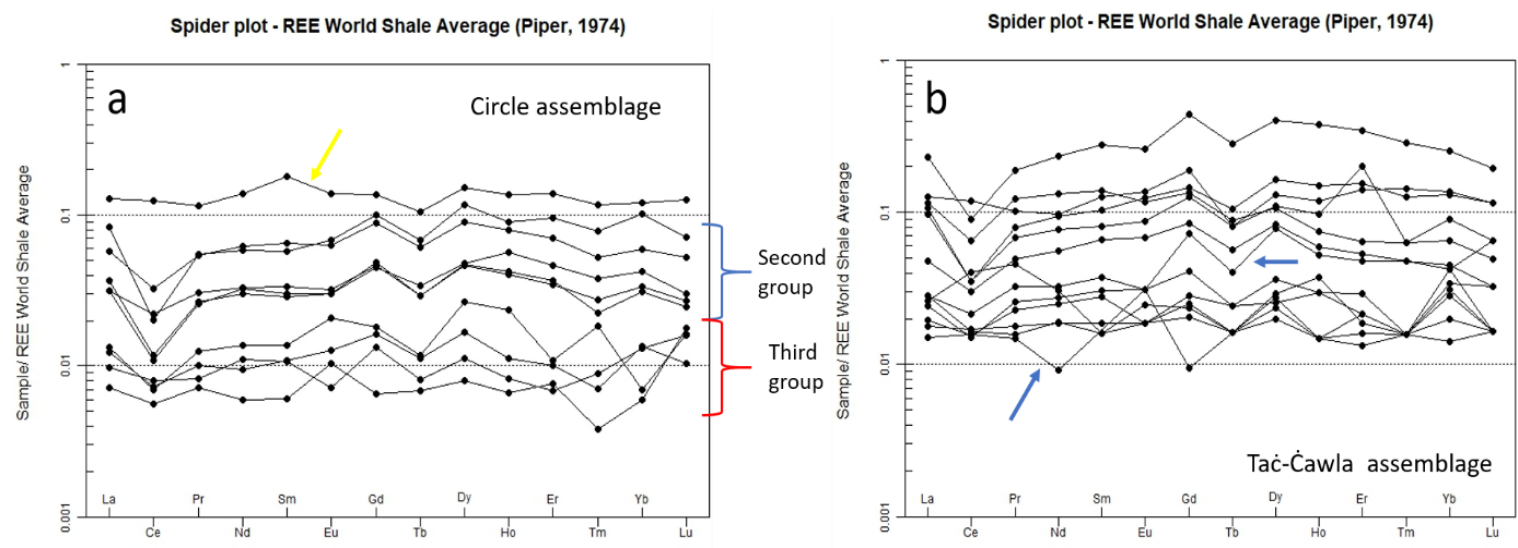

Figure 14. The normalised patterns of rare earth elements of the artefact samples from the Circle and Tać-Cawla assemblages ( $a$ and $b$ ): ( $a$ ) the REE normalised pattern of the samples from the Circle site showing the three different groups and. The yellow arrow shows the artefacts belongs to the first group; (b) the REE normalised pattern of the samples from the Tać-Ċawla site and the blue arrows pointing the two samples (TCC14/S193/L69 and TCCC14/S577/L131) with the significantly fluctuating patterns.

\section{Discussion}

Archaeological research has revealed that the prehistoric communities of Malta showed enormous creativity. Between the first half of the 4 th millennium and the middle of the 3 rd millennium $\mathrm{BC}$, they built large-scale monuments, known as the Stone Temples (Malone et al., 2009). This rare achievement might change our understanding of prehistoric Europe and therefore it is of great importance to understand the circumstances under which these monuments were built and who were their creators. Moreover, it is equally important to seek the degree of connectivity with the neighbouring communities and the influence of those communities on Maltese society. Addressing these issues could provide an insight into the motivation and characteristics of the prehistoric people of Malta who constructed these amazing monuments (Malone et al., 2009). One way to address these issues is by studying the material culture (e.g. pottery, artefacts) related to these monuments. That understanding can provide information on how sophisticated was the prehistoric society that settled on the Maltese Islands, as well as provide insights into the range of the resources they used. The latter will also contribute towards the investigation of the degree of connectivity with neighbouring areas. The possible relation of the Maltese Islands with foreign areas may consequentially raise issues of trade routes and cultural exchange.

There is a commonly held belief that the island of Sicily is the origin of the 'foreign' chert artefacts found on the Maltese Islands (Malone et al., 2009; Vella, 2008). This paper presents the first attempt to test this theory by using macroscopic and geochemical techniques. The research focused on the most important chert outcrops of Sicily and the chert artefacts from two late-Neolithic sites of Malta (i.e. Brochtorff-Xaghra Circle and Tać-Ċawla). The macroscopic characteristics of these artefacts and 
the Sicilian chert sources were recorded. Subsequently an initial grouping was made, and the artefacts of assemblages has been divided into one local and two non-local groups. This is followed by connecting artefacts with Sicilian sources that are macroscopically compatible. The last and most important part of this geoarchaeological approach is to use the geochemical results to test the link between rocks and artefacts.

\subsection{Macroscopic remarks}

The fieldwork on Sicily confirmed that the island has multiple and abundant chert sources. They present great diversity in their macroscopic characteristics, but they clearly differ from the Maltese cherts. They are mainly fine-grained, semi-translucent and shiny which is a combination of features not reported for the Maltese sources. This automatically excludes the artefacts in the assemblages (second group) with similar features to the local sources.

The black, fine-grained and translucent cherts are the most common outcrops found in many the areas of Sicily. On the contrary, the Radiolarian outcrop is a unique formation on northeastern Sicily with no equivalent in another region of the island. The red and green colours, the extensive outcrop and the age (Triassic) are the main characteristics that separate it from the other chert sources. Nonetheless, the fieldwork did not find any chert source that is macroscopically comparable with the artefacts of the first group in two assemblages. The type of brown shades but also the lack of translucency and shine are a combination of features not reported on any of the Sicilian chert sources.

Nevertheless, there are interesting findings related to the artefacts of the third defined group. Many of these artefacts have macroscopic similarities with some of the Sicilian chert sources. Particularly, the macroscopic findings have grouped together one artefact from the Tać-Cawla (TCC14/S416/L178) and one from the Circle assemblages (BR91/S611/L712) (Fig. 15). They are black, heterogeneous, shiny, semi-translucent and fine-grained. Additionally, they have spots that are residues of a chalky cortex. The importance of these finds is their macroscopical resemblance with the black cherts of Sicily (e.g. Monterosso Almo), thus it is possible that these artefacts originate from this island.

However, the macroscopic characteristics fail to distinguish further the different black chert sources of Sicily and the artefacts that might relate to any of them. Moreover, these findings are not sufficient to exclude other areas of Mediterranean with similar chert sources. Therefore, more information is necessary to provide conclusive evidence on the origin of these artefacts. The suite of geochemical techniques has been selected to provide more and stronger evidence of their probable connections. The advantage of this technique is based on the fact that it is impossible for different 
chert sources to have the same geochemical signature. Hence, it allows for their accurate differentiation and will eventually pin-point the probable sources of the chert artefacts.

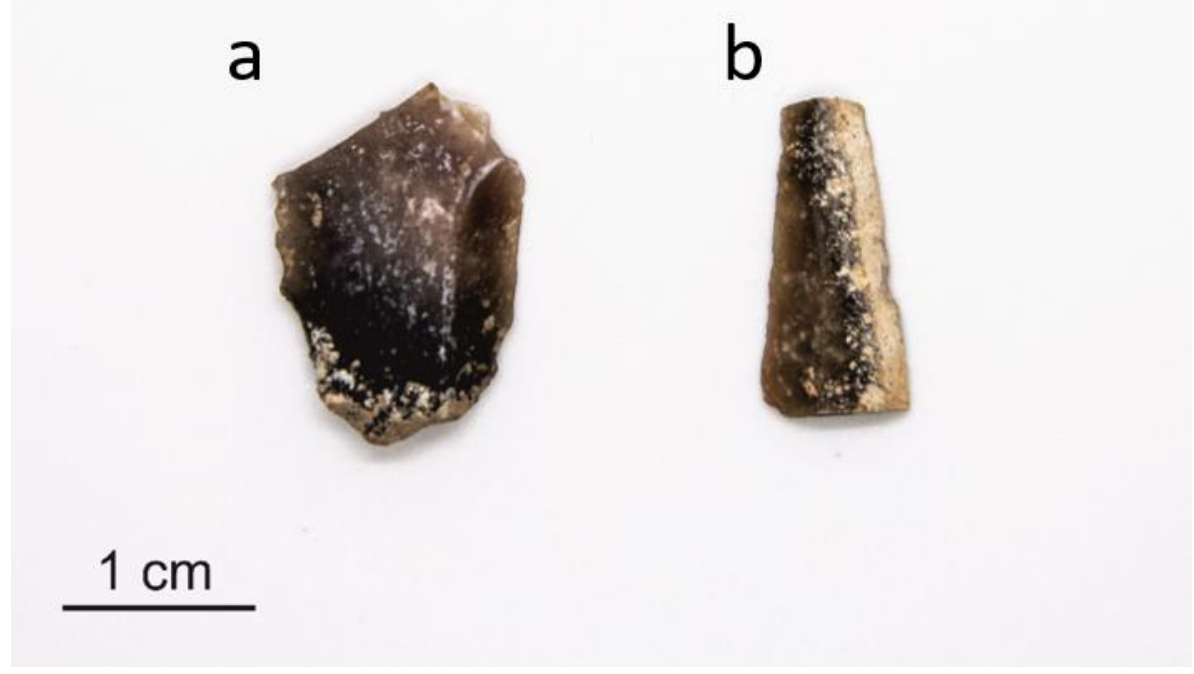

Figure 15. The two similar members of the third group: (a) artefact from the assemblage of Tać-Cawla (TCC14/S416/L178) and (b) artefact from the Circle assemblages (BR91/S611/L712).

\subsection{Geochemical connection of artefacts with their sources}

Starting from the ternary model (Fig. 16), the artefacts are placed in a biogenic sedimentation region and close to each other, with only two of the Sicilian cherts demonstrating such similar features. Similar are the findings from the binary model (Fig. 17) which highlights a further connection with southeastern Sicily. On the contrary, the sources from Monte Judica and western Sicily are excluded from possible sources because they have presented differences in terms of sediments and depositional environment. The same is also applied to the single chert outcrop from the Monterosso Almo area (sample S19), which demonstrates characteristics completely incompatible with the investigated artefacts. These results are further supported by the normalised patterns of REEs (Fig. 18) and creates solid foundations with which to claim that these artefacts are related to specific chert sources from Monterosso Almo (samples S17 and S18) and the Modica area (i.e. sample S3). The concentration levels and patterns between artefacts and outcrops are almost identical, and thus probably these are the sources of these two artefacts. 


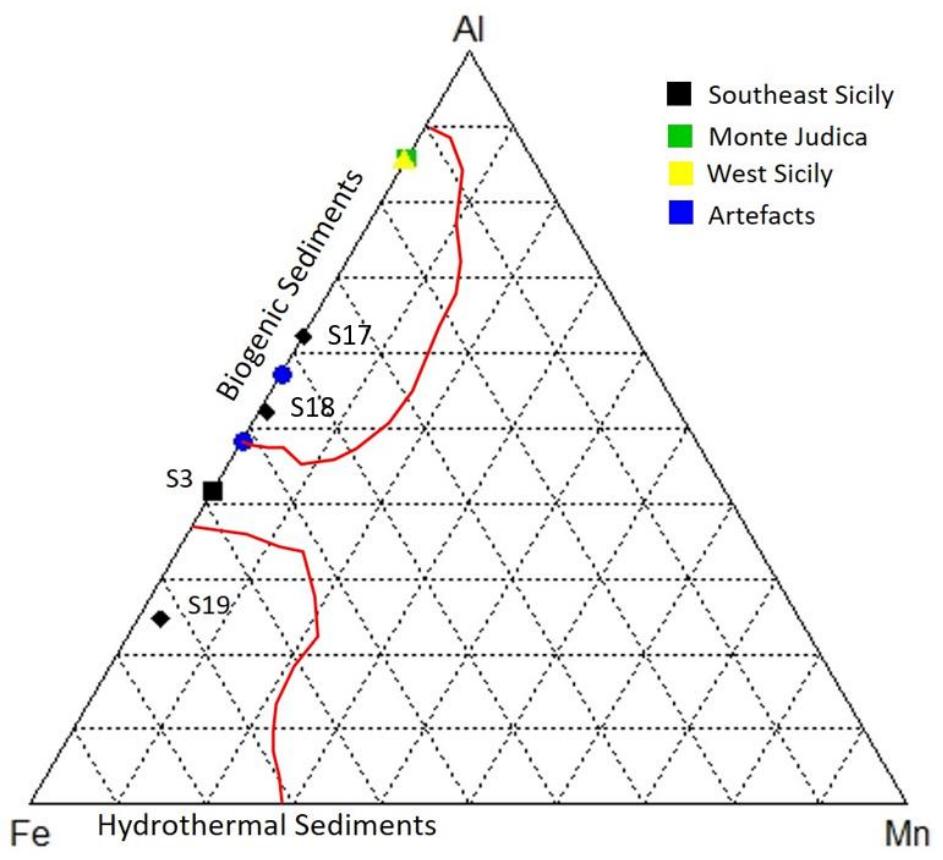

Figure 16. Ternary diagram cross-examining the Sicilian black chert sources and the two artefacts with respect to the type of sediment. The line demarcations have followed the suggestion of Junguo et al. (2011).

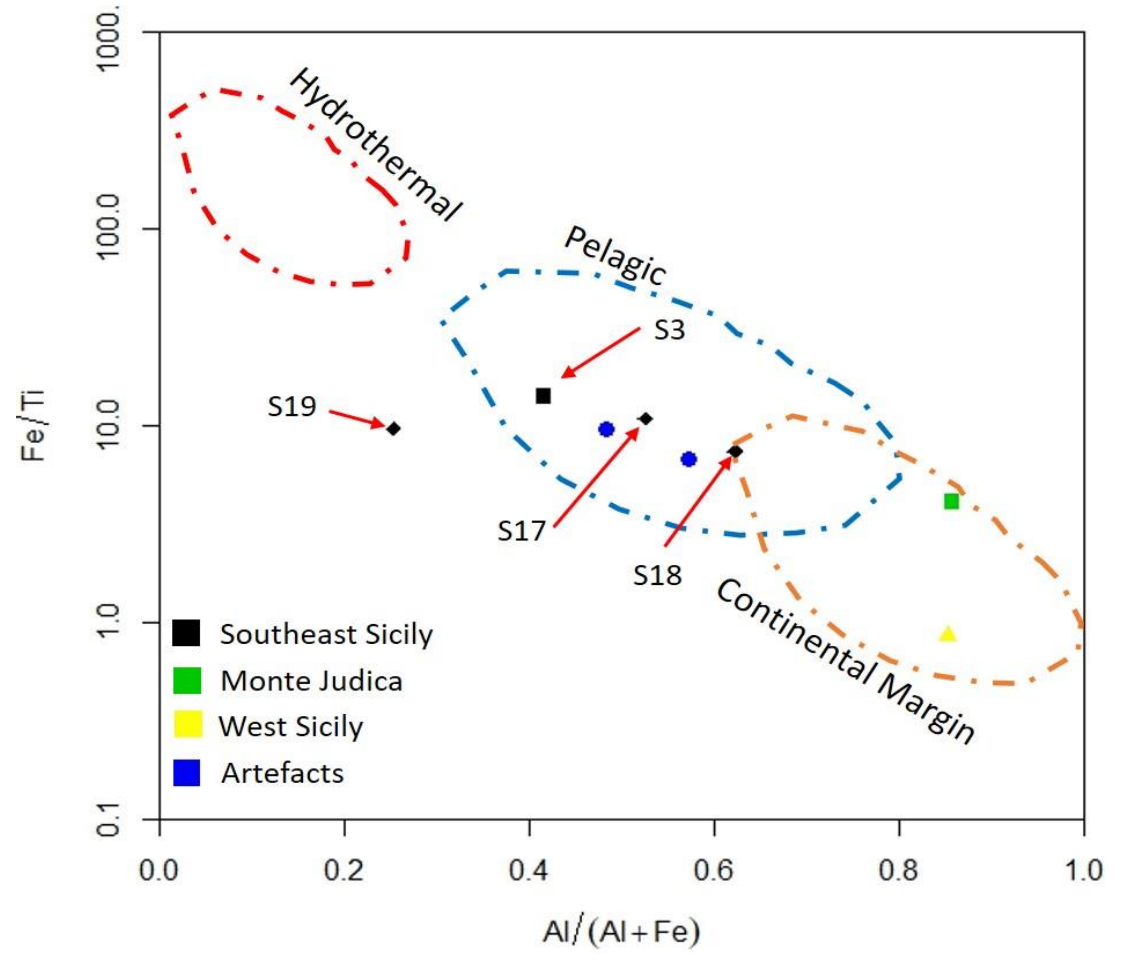

Figure 17. Binary diagram cross-examining the Sicilian black chert sources and the two artefacts with respect to the depositional environment. The line demarcations have followed the suggestion of Murray et al. (1994). 


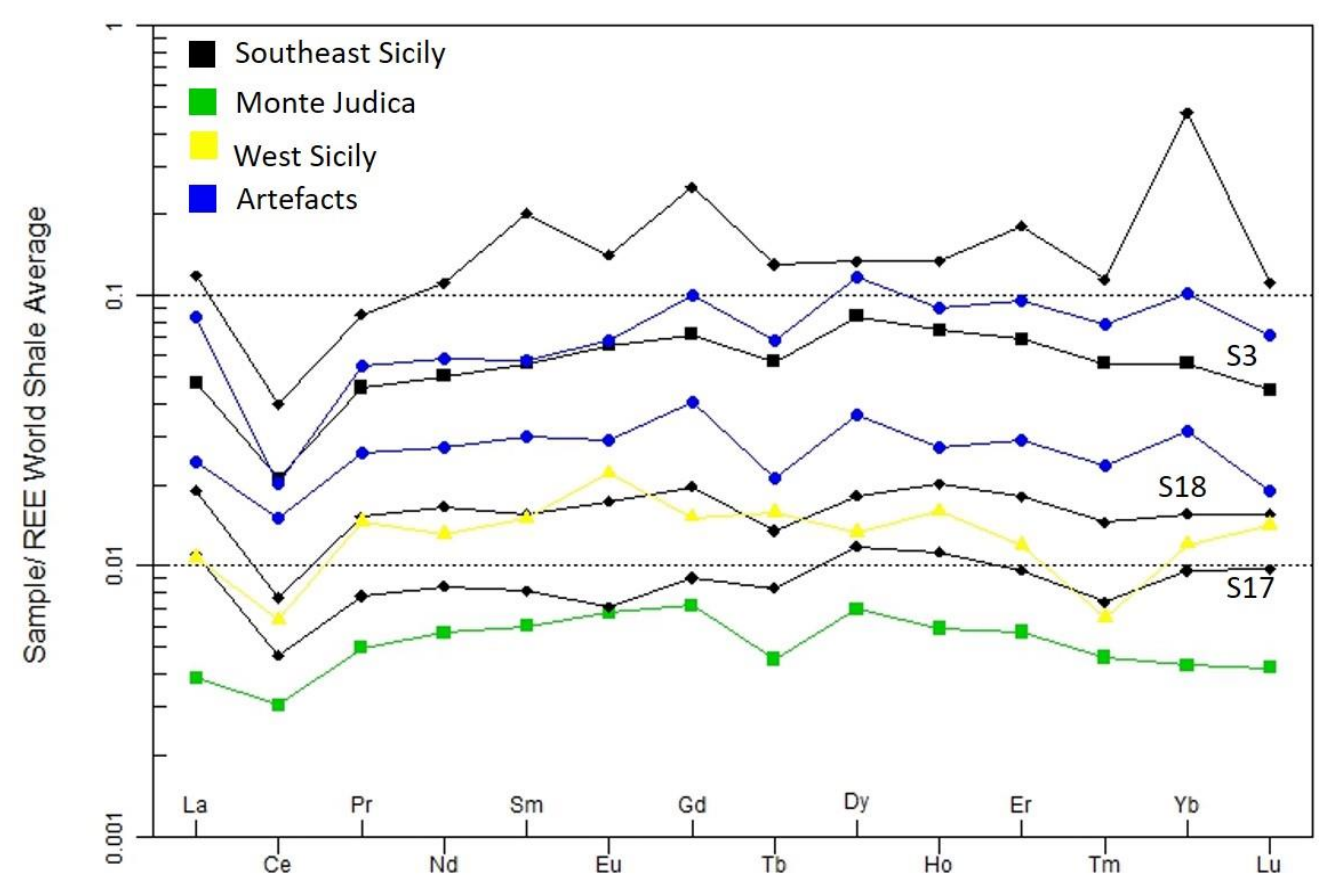

Figure 18. Comparable spider plot of the REE concentrations between the Sicilian black chert sources and the two artefacts.

It is difficult to define which of the two places is the exact location from where the material was exported to Malta. Although there is a great distance between the two areas, the rock samples have been collected from a similar geological formation which explains their proximity in the models. The research is promoting the Monterosso Almo area, based on the better quality of materials, the greater resources and the easiest access to them. However, this must be regarded with caution acknowledging the ability of the prehistoric people to travel great distances and engage in down-the-line exchange. Nonetheless, the research has provided solid evidence that these artefacts relate to the exploitation of specific chert sources from southeastern Sicily.

These findings not only authenticate the connection between these two insular locations but also contribute to other unresolved mysteries of the Neolithic period in the central Mediterranean region. Firstly, this stands as an indirect proof of seafaring activity in the region. Although there is still no evidence of sailing, the only way to reach these islands was by sea. Secondly, this puts the Maltese islands within the proposed Neolithic raw-material network of the region (Tykot, 1996 and 1997). Hence scientifically verifying the exploitation of specific sources for tool crafting and pinpointing source-locations can contribute to accurately reconstructing these networks (Moutsiou and Kassianidou, 2019).

Finally, placing the late-Neolithic community of Malta within those networks suggests that they might actually have access to multiple resources, and this helps to explain how they survived and prospered in a restricted environment. This most likely included human interactions and subsequent 
communications between different societies. Such contacts are not only confided in material but eventually to cultural and technological exchange. Hence, the interactions between communities are considered to have influenced the identity of the individuals and also the structure of their societies.

\section{Conclusion}

The paper has presented a geoarchaeological study of two chert assemblages from Malta and compared them to chert sources of Sicily. The combination of macroscopic observation and geochemistry has separated the artefacts and sources to different groups with distinctive characteristics. In addition, it has provided strong evidence that specific artefacts from these Gozitan Neolithic assemblages are compatible with specific chert sources from southeastern Sicily.

This research has also demonstrated a non-destructive and geologically grounded methodology with promising results for sourcing chert artefacts. It has highlighted that geochemical studies of chert artefacts can make a worthwhile contribution to pin-pointing their sources.

These findings have contributed to a better understanding of the activities within the Neolithic Mediterranean region. Connecting two insular locations indirectly confirms the existence of seafaring and in the meantime puts the Maltese community within a raw-material network. Sourcing the chert artefacts and pinpointing their source-locations can accurately reconstruct these networks, thus providing ideas about the possible scales of social interaction across this region between communities.

\section{Acknowledgements}

I would like to thank Prof. Rosanna Maniscalco (University of Catania) and Prof. Pietro Di Stefano (University of Palermo) who guided me throughout the fieldwork on Sicily Island. Moreover, I will like to thank all the members of FRAGSUS project (under the European Union's Seventh Framework Programme (FP/2007-2013)/ERC Grant Agreement n. 323727, PI Prof. Caroline Malone, Queen's University Belfast, UK) who have contributed towards the successful completion of this research. Special thanks must go to the Anthony Wilkin Fund that provided the necessary funds with which to conduct the fieldwork in Sicily. Finally, we are grateful to the anonymous reviewers for their constructive comments that improve the original manuscript. 


\section{References}

Boggs, S., 2009. Petrology of Sedimentary Rocks, Second Edition. Cambridge University Press, Cambridge, 612p.

Brandl, M., 2010. Chert source areas and provenance studies of chipped stone artifacts in southeastern Crete. Jahreshefte des Österreichischen Archäologischen Institutes in Wien 79, 324341.

Bressy, C.S. D'Anna, A. Poupeau, G. Le Bourdonnec, F.-X. Bellot-Gurlet, L. Leandri, F. Tramoni, P. and Demouche, F. 2008. Chert and obsidian procurement of three Corsican sites during the 6th and 5th millenniums BC. Comptes Rendus Palevol 7, pp. 237-248.

Cann, J.R. and Renfrew, C. 1964. The characterization of obsidian and its application to the Mediterranean Region. Proceedings of the Prehistoric Society, XXXX, pp. 111-133.

Carbone, S. Catalano, S. Grasso, M. Lentini, F. and Monaco, C. 1990. Carta geologica della Sicilia centro-orientale. Scala 1:50.000. S.El.Ca., Firenze.

Catalano, R. 2004. Geology of Sicily: an introduction. Bocconea 17. Palermo, Italy.

Crandell, O. 2006. Macroscopic and Microscopic Analysis of Chert; A Proposal for Standardization of Methodology and Terminology, B.C.S.S., vol. 12, Alba lulia, Romania.

Di Stefano, P. and Vitale, F. 1992. Carta Geologica dei Monti Sicani Occidentali. University of Palermo. IGMI.

Di Stefano, P. Renda, P. and Zarcone. G. 2013. Carta Geologica D' Italia. Sabta Margherita di Belice, Foglio 619. IGMI.

Junguo, H. Yongzhang Z. Hongzhong, Li. 2011. Study on Geochemical Characteristics and Depositional Environment of Pengcuolin Chert, Southern Tibet. Journal of Geography and Geology. Vol. 3, No. 1, pp. 289-290

Larson, M. L. 1994. Toward a holistic analysis of chipped stone assemblages. In Carr, P. (ed.), The Organization of North American Prehistoric Chipped Stone Technologies. International Monographs in Prehistory, Ann Arbor, MI, pp. 57-69.

Lentini, F. 1984. Carta Geologica della Sicilia Sub-orientale. Dai tipi dell'istituto Geografico Militare. Instituto di scienze della terra. University of Catania, Sicily, Italy.

Lentini, F., Carbone, S. and Catalano, S. 1995. Main structural domains of the central Mediterranean region and their Neogene tectonic evolution. Boll. Geofis. Teor. Appl. 36, pp. 141-144.

Luedtke, B. 1992. An archaeologist's guide to chert and flint. Archaeological Research Tools 7, Los Angeles; Institute of Archaeology, University of California.

Maliva, R.G. Knoll, A. H. and Simonson, B. M. 2005. Secular change in the Precambrian silica cycle: Insights from chert petrology. Geol. Soc. Am. Bull., 117, pp. 835-845.

Malone, C. Stoddart, S. Bonanno, A. Trump, D. with Gouder, T. and Pace A. (editors). 2009. Mortuary customs in prehistoric Malta. Excavations at the Brochtorff Circle at Xaghra (1987-1994). McDonald Institute, Cambridge.

Manning, S.W. McCartney, C. Kromer, B. and Stewart, S.T. 2010. The earlier Neolithic in Cyprus: recognition and dating of a pre-pottery Neolithic A occupation. Antiquity 84, pp. 693-706. 
Williams-Thorpe, O. Warren, S. E. and Barfield, L. H. 1979. The sources and distribution of archaeological obsidian in northern Italy. Prehistoria Alpina 15, pp. 73-92.

Masuda, H.,S.A. 1977. Cerium in chert as an indication of marine environment of its formation. Nature Vol. 266, p. 346.

Moutsiou, T. and Kassianidou, V. 2019. Geochemical characterization of carnelian beads from Aceramic Neolithic Cyprus using portable X-ray fluorescence spectrometry (pXRF). Journal of Archaeological Science: Reports, Vol. 25, pp. 257-265.

Murray, R. W. 1994. Chemical criteria to identify the depositional environment of chert: general principles and applications. Sedimentary Geology 90, pp. 213-232.

Murray, R.W. Buchholtzten Brink, M. R. Gerlach, D. C. Price Russ III, G. and Jones, D. J. 1992. Rare earth, major, and trace element composition of Monterey and DSDP chert and associated host sediment: Assessing the influence of chemical fractionation during diagenesis. Geochimica er Cosmuchimico Ada Vol. 56, pp. 2657-2671.

Neff, H. 2012. Laser ablation ICP-MS in archaeology. In Lee, M.S. (ed.), Mass Spectrometry Handbook. Hoboken: Wiley, pp. 829-843.

Odell, G., H. 2000. Stone Tool Research at the End of the Millennium: Procurement and Technology. Journal of Archaeological Research, Vol. 8, No. 4, pp. 269-331.

Pedley, M.H. Clarke and Galea, P. 2002. Limestone isles in a crystal sea: the geology of the Maltese Islands. Enterprises Group, Malta.

Pedley, H.M. 1981. Sedimentology and palaeoenvironment of the southeast Sicilian Tertiary platform carbonates. Sedimentary Geology 28 (4), pp. 273-291.

Pelegrin, J. 1990. Prehistoric lithic technology: Some aspects of research. Archaeological Review from Cambridge 9, pp. 116-125.

Robb, J.E. and Farr, R.H. 2005. Substances in motion: Neolithic Mediterranean "trade". In: Blake, E., Knapp, A.B. (eds.), The Archaeology of Mediterranean Prehistory. Blackwell, Oxford, pp. 24-45.

Shen, B. Maa, H. Yea, H. Langa, X. Peic, H. Zhoub, C. Zhangd, S. and Yang, R.2018. Hydrothermal origin of syndepositional chert bands and nodules in the Mesoproterozoic Wumishan Formation: Implications for the evolution of Mesoproterozoic cratonic basin, North China. Precambrian Research, vol. 310, pp. 213-228.

Skarpelis, N. Carter, T. Daniel, A. Contreras, D.A. Mihailović, D.D. 2017. Characterization of the siliceous rocks at Stélida, an early prehistoric lithic quarry (Northwest Naxos, Greece), by petrography and geochemistry: A first step towards chert sourcing. Journal of Archaeological Science: Reports, Vol. 12, pp. 819-833.

Speer, C., A. 2014. Experimental sourcing of Edwards Plateau chert using LA-ICP-MS. Quaternary International 342, pp. $199-213$.

Tucker, M.E. 2001. Sedimentary Petrology. Blackwell, Scientific Publication, London

Tykot, R. H. 1996. Obsidian procurement and distribution in the central and western Mediterranean. Journal of Mediterranean Archaeology 9, pp. 39-82. 
Tykot, R. H. 1998. Mediterranean islands and multiple flows: the sources and exploitation of Sardinian obsidian. In book (ed. Shackley): Method and Theory in Archaeological Volcanic Glass Studies. Advances in Archaeological and Museum Science $3^{\text {rd }}$ Series. New York: Plenum, pp. 67-82

Vella, C. 2008. Report on the lithic tools of Sicilian origin from the prehistoric site of Skorba, Malta. In A. Bonanno (ed.), Malta and Sicily: Miscellaneous Research Projects. edited by A. Bonanno. Officina di Studi Medievale, University of Malta, Palermo.

Williams-Thorpe, O. 1995. Review article. Obsidian in the Mediterranean and the Near East: a provenancing success story. Archaeometry 37, pp. 217-248. 